Proceedings of the Prehistoric Society 83, 2017, pp. 97-135 () The Prehistoric Society. This is an Open Access article, distributed under the terms of the Creative Commons Attribution licence (http://creativecommons.org/ licenses/by/4.0/), which permits unrestricted re-use, distribution, and reproduction in any medium, provided the original work is properly cited.

doi:10.1017/ppr.2017.4 First published online 19 September 2017

\title{
Stepping Stones to the Neolithic? Radiocarbon Dating the Early Neolithic on Islands Within the 'Western Seaways' of Britain
}

\author{
By DUNCAN GARROW ${ }^{1}$, SEREN GRIFFITHS ${ }^{2}$, HUGO ANDERSON-WHYMARK ${ }^{3}$ and FRASER STURT $^{4}$
}

The western seaways - an arc of sea stretching from the Channel Islands in the south, up through the Isles of Scilly, the Isle of Man, and the Outer Hebrides to Orkney in the north - have long been seen as crucial to our understanding of the processes which led to the arrival of the Neolithic in Britain and Ireland in the centuries around $4000 \mathrm{cal}$ BC. The western seaways have not, however, been considered in detail within any of the recent studies addressing the radiocarbon chronology of the earliest Neolithic in that wider region. This paper presents a synthesis of all existing 5th and 4th millennia cal $B$ C radiocarbon dates from islands within the western seaways, including 50 new results obtained specifically for this study. While the focus here is insular in a literal sense, the project's results have far reaching implications for our understanding of the Mesolithic-Neolithic transition in Britain and Ireland and beyond. The findings broadly fit well with the Gathering Time model of Whittle et al., suggesting that the earliest dated Neolithic in this zone falls into the c. 3900-3700 cal BC bracket. However, it is also noted that our current chronological understanding is based on comparatively few dates spread across a large area. Consequently, it is suggested that both further targeted work and an approach that incorporates an element of typo-chronology (as well as absolute dating) is necessary if we are to move forward our understanding of the processes associated with the appearance of the first Neolithic material culture and practices in this key region.

Keywords: Mesolithic, Neolithic, Mesolithic-Neolithic transition, radiocarbon dating, islands, maritime archaeology, western seaways

\section{INTRODUCTION}

The manner in which 'the Neolithic' arrived in Britain and Ireland was a topic of debate throughout the 20th century (eg, Case 1969; Kinnes 1988; see Thomas 2013 and Anderson-Whymark \& Garrow 2015 for recent reviews). In the early 21 st century, there has been a significant resurgence of interest in the issue (eg, Sheridan 2010; Whittle et al. 2011; Thomas 2013). Most discussions since the early 20th century have

\footnotetext{
${ }^{1}$ Department of Archaeology, University of Reading, Reading RG6 6AB Email: d.j.garrow@reading.ac.uk

${ }^{2}$ School of Forensic and Applied Sciences, University of Central Lancashire, Preston PR1 2HE

${ }^{3}$ Department of Archaeology, University of York, York Y01 7EP

${ }^{4}$ Archaeology, University of Southampton, Southampton SO17 1BF
}

focused on the processes by which Neolithic practices arrived in Britain and Ireland from continental Europe. The main issue under consideration has been the relationship between, and relative roles played by, incoming 'Neolithic' migrants/colonists from the continent and the indigenous 'Mesolithic' populations of Britain and Ireland. For a long while, this debate could be characterised as one between those arguing for substantial colonisation from the continent (eg, Sheridan 2010) versus those arguing that the indigenous population had been almost exclusively responsible for the transition (eg, Thomas 2008). More recently, however, it has become increasingly common for interpretations to stress a combination of the two (eg, Garrow \& Sturt 2011; Whittle et al. 2011, 861; Cummings \& Harris 2011; Thomas 2013, 423-4; Anderson-Whymark \& Garrow 2015). 
RECENT CHRONOLOGIES OF THE MESOLITHIC-NEOLITHIC TRANSITION

Over the past few years, in addition to these longstanding discussions of process, the chronology of the Mesolithic-Neolithic transition in Britain and Ireland has received a great deal of attention - primarily as a result of new syntheses and different interpretations of the radiocarbon evidence. Discussions of chronological data, both in terms of approaches to the evidence and the interpretation of chronologically diagnostic material culture from key sites, have been central. Different readings of these evidence sets have led to sometimes radically different interpretations. Critical to all of these discussions are not just their uses of chronological evidence, but also the way in which they draw the evidence from different regions into wider models in an attempt to understand the processes of transition.

In 2010, Sheridan presented a four-strand 'Neolithisation' model drawing on previous work (eg, Sheridan 2000; 2003; 2004; 2007; see Fig. 1). The first two phases involved a 'false start' of contact between west and north-west France and south-west Ireland c. 4500-4250 and a Breton/'Atlantic' strand of contact between western France and western Britain/northern Ireland c. 4300-4000 BC (Sheridan 2010, 91-101). Sheridan's model included only a small number of radiocarbon dates, foregrounding the monument and ceramic typo-chronologies of France, Britain, and Ireland to develop a spatio-temporal narrative of Neolithic introductions.

In the same year, Collard et al. (2010) published their review of radiocarbon evidence, incorporating 4246 dates from 1762 'site phases' across Britain (Fig. 1). In 'an effort to move the [indigenous adoption versus migration] debate forward' they employed 'changes in summed probability distributions of calibrated 14C dates derived from different site phases [to] serve as a proxy for changes in population size' (Collard et al. 2010, 867). The inferred population growth rate subsequently identified was viewed as the result of 'incoming farmers'. As a result, Collard et al. (2010, 867-9) suggested that south-west England (ie Wessex) was the first area to witness population increase, inferred to have been brought on by the arrival of the Neolithic through incoming migration from c. $4100 \mathrm{cal}$ BC. Since 2010, the Collard et al. team have updated, but not substantially altered the results or conclusions of, their earlier work in various papers (eg, Shennan et al. 2013; Timpson et al. 2014).
One year later, Whittle et al. (2011) published their study of the radiocarbon evidence for causewayed enclosures in Britain and Ireland, and radiocarbon dates associated with Early Neolithic material culture in selected regions, in their substantial Gathering Time volume. While the primary focus of this project was causewayed enclosures, work by Whittle et al. on the wider context within which these monuments were first constructed enabled them to consider the arrival of 'Neolithic things and practices' (as they put it) in Britain and Ireland more generally (Fig. 1). Their study - involving a corpus of 2350 heavily scrutinised radiocarbon dates - ensured that Gathering Time introduced a new quality of understanding in relation to the timing and tempo of change. Whittle et al. suggested that the earliest signs of the Neolithic in Britain and Ireland arrived in south-east England probably in the 41st century cal BC; 'the Neolithic' then spread across central southern England over the next two centuries, followed by an especially rapid and extensive phase of expansion right across Britain and Ireland in the decades around $3800 \mathrm{cal} \mathrm{BC}$ (Whittle et al. 2011, 836).

Subsequent to the publication of Gathering Time, new evidence from Ireland, examining indicators for early farming practices and for the construction of Neolithic houses, also suggests a distinct disjuncture in terms of practices in the 38th century cal BC (McClatchie et al. 2014). Evidence from other regions of Britain (the Midlands, the north of England, and north Wales), studied in parallel with Whittle et al., indicates that this period was also a time of significant change elsewhere (Griffiths 2014a; 2014b), including for the first time evidence for people using characteristic Mesolithic microlith technology at the same time as people were constructing Neolithic monuments and pottery in different parts of the landscape in Yorkshire.

\section{Critiques of these approaches}

The three key approaches outlined above have been critically scrutinised since their publication. Sheridan's (2010) model has been questioned in various ways, not least for the fairly direct relationship she saw between the movement of objects/object styles and the movement of people (Thomas 2013, 159-73). With specific reference to chronology, Sheridan has been criticised for using selective 'visual inspection' (rather than detailed chronological modelling) of radiocarbon dates and for employing a 'loose' chronology relating 
D. Garrow et al. RADIOCARBON DATING ON ISLANDS WITHIN THE 'WESTERN SEAWAYS' OF BRITAIN
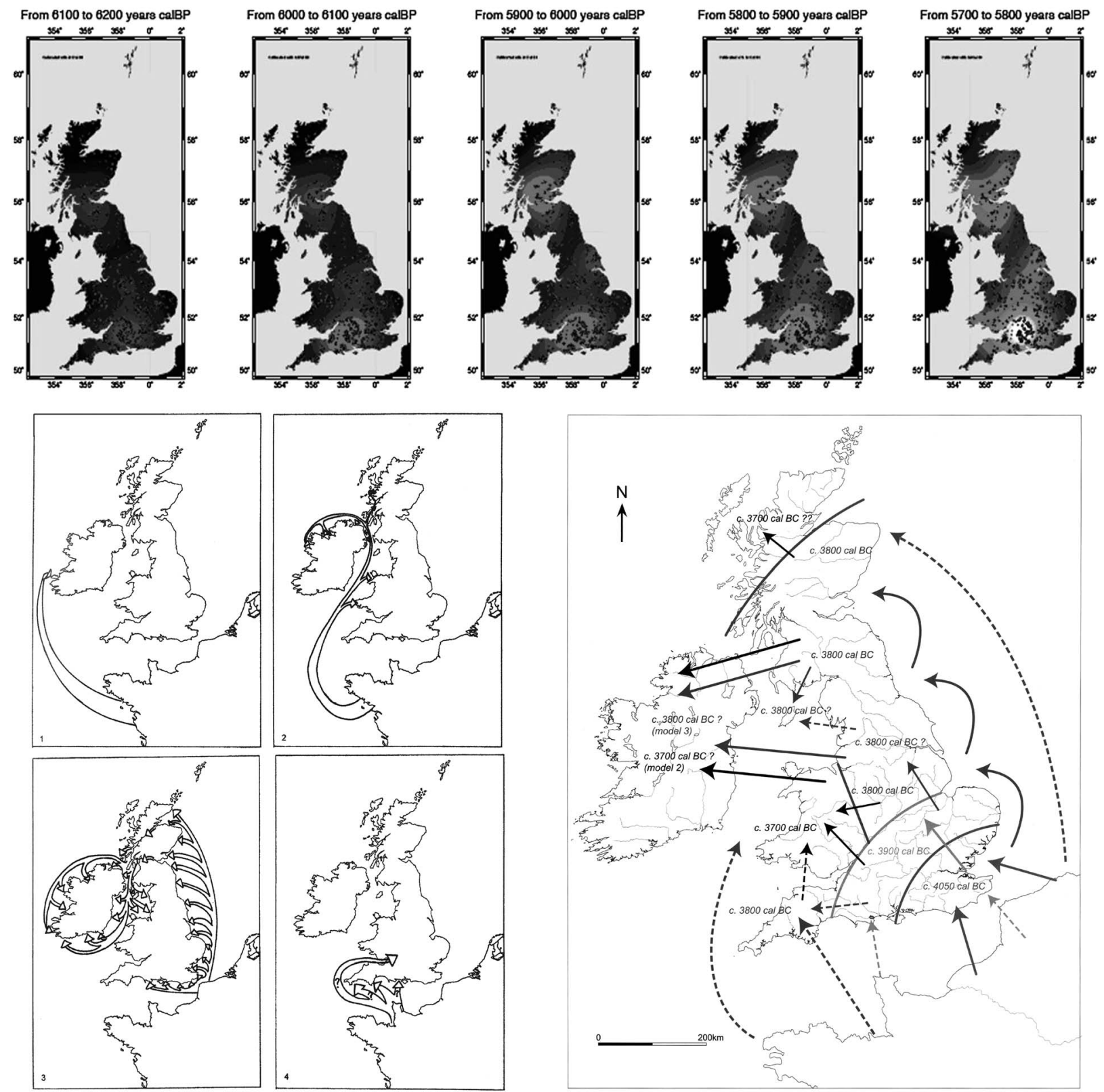

Fig. 1.

The arrival of the Neolithic in Britain and Ireland, as depicted within: (top) Collard et al. 2010, 868, originally in colour; (bottom left) Sheridan 2010, 93; and (bottom right) Whittle et al. 2011, 869, originally in colour

to the continental source areas from where artefacts and hence people - are supposed to have originated (Whittle et al. 2011, 849-50).

The model put forward by Collard et al. (2010) has been heavily critiqued in terms of their approach to archaeological evidence and their mathematical treatment of radiocarbon data (eg, Chiverell et al. 2011; Contreras \& Meadows 2014). As Sheridan and Pétrequin $(2014,373)$ note, some of their 'basic assumptions ... are highly contentious', while Thomas $(2013,219)$ emphasises that the lack of consideration of the effects of various biases within their method may 
well have resulted in 'entirely spurious patterns'. In archaeological terms, three key aspects have been substantially criticised. First, that numbers of any kind of archaeological evidence can be equated directly with human population, especially given regional research biases in the procurement of radiocarbon measurements (Thomas 2013, 219; Sheridan \& Pétrequin 2014, 373; see also Armit et al. 2013; Crombé \& Robinson 2014); second, that their approach includes no assessment of the association of diagnostic material culture with radiocarbon data, and thus cannot be used to infer the presence of Mesolithic or Neolithic lifeways; and third, in terms of the statistical interpretation of summed distributions, caution should be exerted in terms of what these distributions reflect. As Bronk Ramsey (2009a) notes, these statistics cannot be used as a substitute for proper Bayesian analysis as they take no account of the grouping of radiocarbon data as a result of the underlying sample.

Given the significant impact that Gathering Time has had on our understanding of the chronology of the Early Neolithic, it is interesting to observe that there has in fact been relatively little critique of the work of Whittle et al. so far. One factor in this is perhaps that the high quality and sheer scale of their modelling has (inadvertently) intimidated people into overwhelming consent. Sheridan $(2012,262)$ has described it as a 'magnificent ... magnum opus', while Thomas (2013, 221) has suggested that it 'will provide the framework for our understanding of the earlier Neolithic for some time to come'. In addition, the vast scale of the analysis means that it is often difficult to situate smaller site-specific or regional analyses against the Gathering Time regional models. It was, for example, beyond the scope of this project to recode them.

Sheridan has provided the most sustained criticism of Gathering Time's interpretations. In her Antiquity review of the book (Sheridan 2012) she was primarily concerned with defending robustly her own position. A more recent discussion, however, has highlighted their 'over-reliance on radiocarbon dating at the expense of a more holistic approach' (Sheridan \& Pétrequin 2014, 372). Those authors emphasise that Gathering Time's conclusion - that the Neolithic started in south-east England and spread north and west - reflects only 'the earliest radiocarbon-dated evidence for the presence of Neolithic things and practices'. In short, they argue, if there was an even earlier Neolithic presence in the west of Britain - as Sheridan has long suggested - and research biases mean that this evidence has simply not been dated, the Gathering Time reliance on radiocarbon would not identify any indications of that earlier presence (Sheridan \& Pétrequin 2014, 373, original emphasis). Sheridan and Pétrequin also suggest that there is a discrepancy between the overall nationwide visualisation of gradually-spreading change propounded by Whittle et al. and the more patchy, much less evenlyspreading image of change presented at other points within the volume. Thomas $(2013,221)$ also suggested that we need to accept these arguments 'critically and cautiously'.

Interestingly, and much to their credit, probably the most detailed critique of the Gathering Time model comes from the book's authors themselves. Throughout the book, they made clear the problems that arise in relation to our understanding of the arrival of the Neolithic more generally - as a result of the fact that their dating programme focused primarily on causewayed enclosures, which are located mainly in the south-east: 'this project was designed to investigate enclosures. Our comparative models are reliant on the existing corpus of radiocarbon dates, which is of variable quality. Our understanding of the chronology of enclosures is consequently much more robust than our models for the dating of other Neolithic things and practices' (Whittle et al. 2011, 846). They also acknowledged that, for various reasons, certain key areas were not considered (ibid., 822), and that their use of a sample of dates from Scotland south of the Great Glen was merely a 'preliminary attempt' at approaching cross-Britain coverage (ibid., 16). They also pointed out that their broader small-scale visualisations of change (eg, ibid., fig. 15.8) may well mask a more complicated and less smoothly-changing reality: 'the general trajectory of change from south-east to north-west across Britain may conceal a more complicated process' (ibid., 835). Their decision to present this scale of interpretation of the process was a very conscious one, as they felt that a large-scale, more detailed analysis of regional change would require even more dates and even more detail than presently available. They also made very clear that their chronological models were necessarily completely dependent simply on what has been found. For example, they highlighted the fact that arguably their most important model - which places the earliest dated Neolithic evidence in Britain in the Greater Thames estuary - depends on 37 (out of a total of 41) dates on recently excavated samples (Whittle et al. 2011, 741). 


\section{Garrow et al. RADIOCARBON DATING ON ISLANDS WITHIN THE 'WESTERN SEAWAYS' OF BRITAIN}

Without this aspect of the dataset, the overall picture of change associated with the start of the Neolithic would have been very different; thus the contingencies of excavation and recovery were made very clear.

To summarise, the key issues that people (not least the authors themselves) have raised in relation to the now-dominant chronological model for the introduction of the Neolithic presented in Gathering Time are:

- The model is inevitably biased towards radiocarbon dated sites and well-dated regions;

- The project's primary focus on causewayed enclosures resulted in a better understanding of the south and east than other regions;

- Certain regions, in the north of England, north of Scotland and Wales, were not considered at all within the overall model;

- The resultant understanding of the arrival and spread of other 'Neolithic things and practices' is not as solid as our understanding of the chronology of causewayed enclosures; and

- The broad-brush picture of south-east to northwest spread presented in their nationwide-scale model potentially masks the existence of regional complexities.

We will pick up on many of these issues in relation to our own study towards the end of this paper. Ultimately, the strengths of Gathering Time are in some ways also its weaknesses. It has become such a significant piece of work in relation to our understanding of the Early Neolithic in Britain and Ireland because of the ambitious scope of its geographical coverage and analysis. Yet the scale at which the overall summary narrative is drawn necessarily demands that certain subtleties of the archaeological evidence are underemphasised. It must be acknowledged that these complexities are often present in the more detailed regional chapters, but inevitably become less visible when nationwide-scale models are discussed. In the remainder of this paper, we consider in detail one key region that was not included in the Gathering Time overview.

\section{'IMPORTANT BUT PATCHY': THE WESTERN SEAWAYS ZONE}

'Since this [review of the dating evidence from Scotland] is an indicative exercise only, with no claims to completeness, we have chosen to exclude dates from north of the Great Glen, consciously here leaving aside the important but patchy radiocarbon dating evidence from the Western Isles, Caithness, and the Orkney and Shetland Islands' (Whittle et al. 2011, 822).

This description of the northern and western isles (among other places) as important to any understanding of the process of transition, yet patchy in terms of the quality and quantity of radiocarbon dates available might well be applied to the 'western seaways' zone in general. In the next section, we outline why this geographical area (Figs 2-3) is vitally important to any overall understanding of the Mesolithic-Neolithic transition in Britain and Ireland. We will then move on to address the patchiness of the radiocarbon record relating to that zone, addressing what the available evidence - including additional data generated as part of this project - can tell us about the nature of the earliest Neolithic in this zone.

In two recent papers (Garrow \& Sturt 2011; Anderson-Whymark et al. 2015), we have highlighted the importance of the western seaways in terms of achieving an understanding of the cross-Channel connections and broader cultural processes that led to the arrival of the Neolithic in Britain and Ireland in the centuries around $4000 \mathrm{cal} \mathrm{BC}$, following a 'delay' of around 1000 years since the Neolithic arrived in north-west France (see also Thomas 2013, 259-84). In doing this we are not making a new observation, but building on a discourse that has slipped in and out of focus since the early 20th century. Crawford (1912; 1936) and Fox (1938) stand as notable proponents of the western seaways as a crucial vector for communication (Fig. 2). Crawford (1936, 181), for example, argued that we are too 'accustomed to think of prehistoric man as living a sedentary life and as not wanting to make long journeys by land or sea' and that actually we should instead see movement over water as 'a normal feature of primitive life'.

Both Crawford and Fox appear to have been inspired by the earlier work of Mackinder (1902) on Britain and the sea. Mackinder's scholarship painted a vivid picture of the differing textures and qualities of the water that surrounds Britain and Ireland. However, perhaps most significantly he tied those qualities to historical trajectories, demonstrating how the ebbs and flows of tidal patterns, distances across the water, and the distribution of islands and inlets impacted on connectivity. For Mackinder (1902, 23), and many of those who have followed, the seas that surround Britain could be split into four zones: 'to the east and south are the narrow seas between the islands and the continent. 


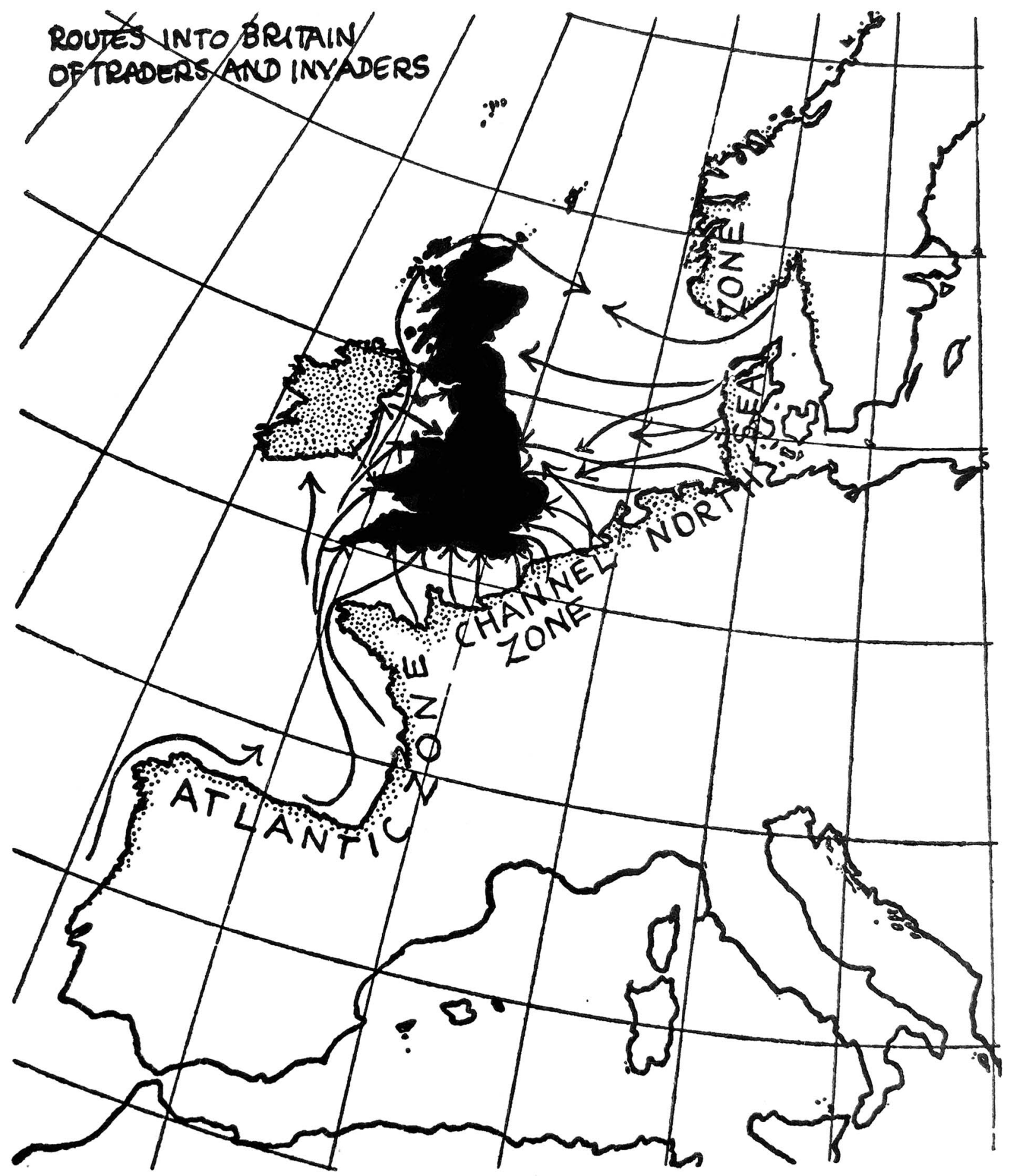

Fig. 2.

Connections between the near continent and Britain/Ireland according to Fox (1938, front cover) 


\section{Garrow et al. RADIOCARBON DATING ON ISLANDS WITHIN THE 'WESTERN SEAWAYS' OF BRITAIN}

To the south-west is the marine antechamber dividing into channels at the Land's End. Spreading four square in the midst of the British Kingdoms is the inland Irish sea: while for six hundred miles off the north-western shores is the border of the ocean'. He noted that the prominence of each of these different seaways varied through time; while at some points 'Kent was the window by which England looked into the great world', at others it was across the narrow (North) sea or through the aperture of the western seaways (Mackinder 1902, 10). Together Mackinder, Crawford, and Fox helped to establish that movement over water should be seen as routine, that we should not expect a single point of contact since lines of communication change through time, and that an understanding of maritime connectivity is required in order to understand distributions of archaeological material.

The western seaways have returned to prominence in relation to the transition in recent years thanks especially to Sheridan's (2010) 'four strand' model of 'Neolithisation' - her first two strands of contact are located across them. Even if the critique by Whittle et al. of key aspects of her model (discussed above) is accepted, the western seaways can still be seen as vitally important to our appreciation of maritime connectivity during the 5th millennium cal $\mathrm{BC}$, since all of the significant potential glimpses of pre-Neolithic crossChannel contact have come from within that zone. These include the assemblage of northern French/ Belgian-style microliths from Old Quay, Isles of Scilly potentially dating to as late as the 5 th millennium cal BC (Anderson-Whymark et al. 2015; Garrow \& Sturt in press); the cow bones from Ferriter's Cove, County Kerry, Ireland, recovered on an otherwise Mesolithic site and radiocarbon dated to $4495-4195 \mathrm{cal}$ BC (Woodman \& McCarthy 2003, 33); and the causewayed enclosure found at Magheraboy, Co. Sligo, Ireland where activity began in 4115-3850 cal BC $(95 \%$ probability; Whittle et al. 2011, 584, fig. 12.20; Start Magheraboy), which thus appears to represent a very early monument of its form (although see Whittle et al. 2011, 574-85 for discussion of the complex arguments surrounding the dating of this site). These sites emphasise that even if the Gathering Time model is broadly correct in placing the earliest significant arrival of Neolithic things and practices in south-east England, there could also have been different (and potentially earlier) trajectories of change occurring along and around the western seaways.

\section{THE NEOLITHIC STEPPING STONES DATING PROJECT}

This paper, like the wider Arts and Humanities Research Council-funded project from which it derives Stepping stones to the Neolithic? Islands, maritime connectivity and the 'western seaways' of Britain, 5000-3500 BC - focuses primarily on five offshore island groups within the western seaways of Britain: the Channel Islands, the Isles of Scilly, the Isle of Man, the Outer Hebrides, and Orkney (Fig. 3). The broader Stepping Stones project aimed to address the fact that our knowledge of the archaeology of the western seaways during the crucial period (c. 5000-3500 cal BC) was limited, despite having long been suggested as an important corridor of interaction. Its central research question was: what does the evidence for the earliest Neolithic material culture within the western seaways of Britain tell us about the processes and timing of the Mesolithic-Neolithic transition in (and around) Britain and Ireland? In order to answer this, we focused on three subsidiary questions:

1. When did Neolithic material culture arrive on each island group within the western seaways?

2. What is the character of the earliest Neolithic evidence on each island group?

3. What was the character of the sea during this period, and how would it have affected seafaring practice?

The present paper deals primarily with question 1 (see Garrow \& Sturt forthcoming and Sturt et al. 2013 for considerations of the other two). In order to understand better the chronology of Early Neolithic sites in the western seaways zone, the dating project outlined in this paper sought a. to collate all relevant existing radiocarbon dates from that area, and b. to obtain additional new radiocarbon dates from a selection of key sites.

\section{METHODS}

Our first step was to create a new database of all potentially Late Mesolithic and Early Neolithic archaeological sites with radiocarbon results falling within the 5th and 4th millennia cal BC on the relevant island groups. We also noted sites, both published and unpublished, which appeared to have potential for radiocarbon dating but had not yet been radiocarbon dated. All existing radiocarbon dates were collated from published sources, including Historic Environment Record datasets, the Council for British Archaeology's 'Archaeological Site Index to Radiocarbon 


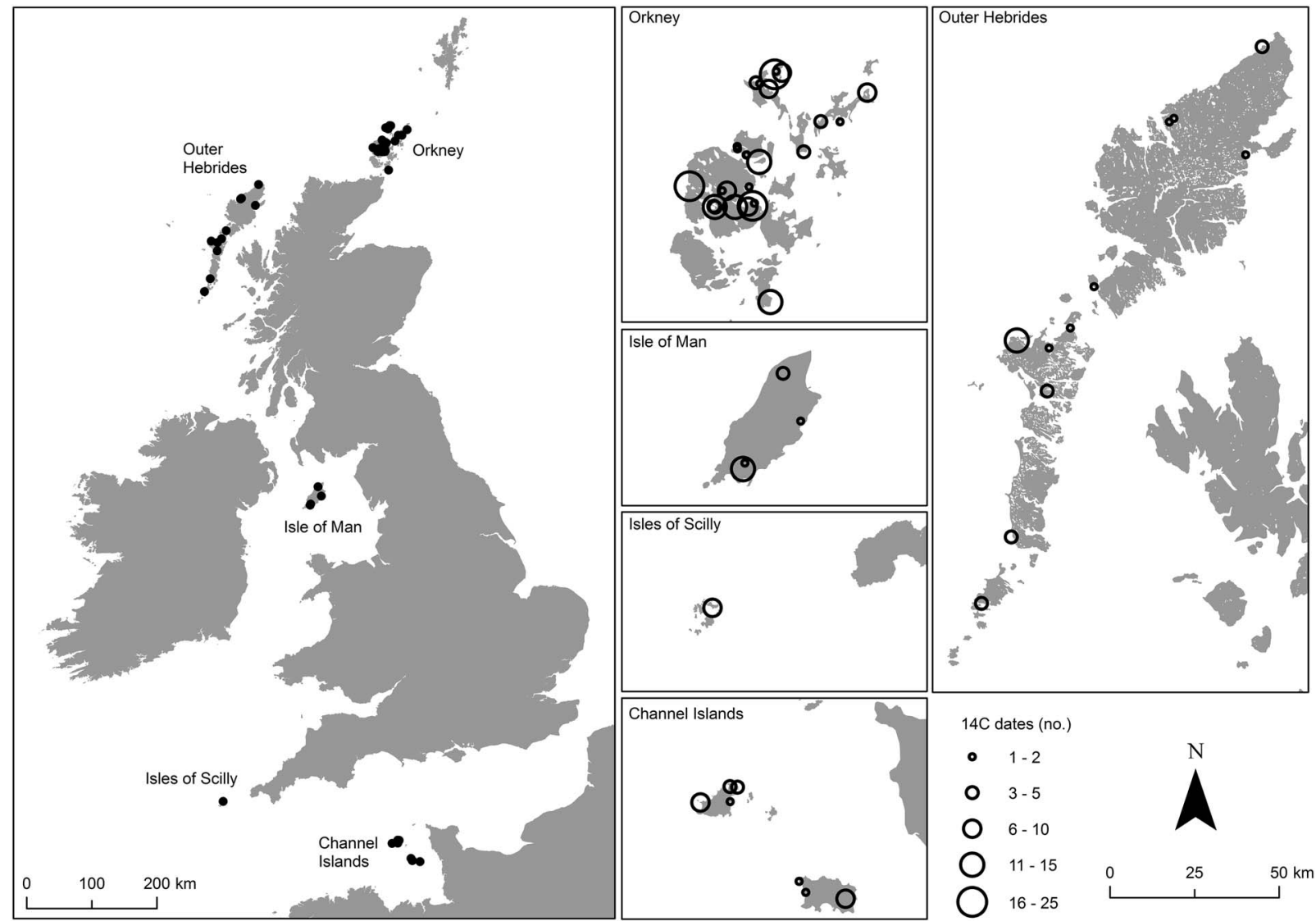

Fig. 3.

Locations of all radiocarbon dated sites within the five island groups, including information about number of dates per site. All islands are shown to the same scale

Dates from Great Britain and Ireland', the Scottish Radiocarbon Database on CANMORE and 'Radiocarbon Dates' in Discovery and Excavation in Scotland. For published sites, excavation reports were consulted and data cross-referenced with other sources. Unpublished radiocarbon dates were incorporated in the dataset by express permission of the parties who obtained the measurements. Following completion of the database, published sites with published dates were reviewed to assess the extent and character of previous dating programmes (eg, stratigraphic relationships and sample selection), and the presence/absence of further suitable materials for dating. In addition, the potential for radiocarbon dating the previous sites was investigated.

From the numerous sites identified in the database as having potential for further radiocarbon dating, it was necessary to select material with the capacity to provide additional data on the Early Neolithic in the respective regions. Two types of site were defined. Those which appeared likely to fall within the relevant period but remained as yet completely undated, and those which had seen some previous work in terms of radiocarbon dating but which had potential to have sequences refined by additional dates. Appropriate samples for all relevant sites were located where possible and assessed. Additionally, our own recent excavations in Guernsey, the Isles of Scilly, and South Uist produced further suitable samples for dating. In 2013, we made a successful application to the National Environment Research Council radiocarbon facility (NRCF) for funding enabling us to obtain 40 new dates; in 2014, following a second season of work at Old Quay, St Martin's, we were successful in 


\section{Garrow et al. RADIOCARBON DATING ON ISLANDS WITHIN THE 'WESTERN SEAWAYS' OF BRITAIN}

obtaining 10 additional NRCF-funded dates for that site. The method of sample selection described in Gathering Time (Whittle et al. 2011, 38-42) was followed as a guideline for procedures throughout.

It is important to be clear that in our own NRCF application for new dates we focused intentionally only on settlement/occupation sites, not on burial monuments. We made this decision in order to maintain the primary focus of the Stepping Stones project on settlement sites, to ensure that our dating programme remained focused and manageable within the scope of that broader project, and to avoid further substantial analysis of human bone. A parallel project focusing on the dating of tombs would certainly be feasible (and desirable) in future. Our broader dataset of pre-existing radiocarbon results contains all known dates from the five island groups, including many from burial monuments (see Appx S.3).

In presenting the dataset here, we have applied a cut-off end point of $3000 \mathrm{cal}$ BC, ensuring that approximately the first millennium after the transition in Britain and Ireland is covered. Sites with radiocarbon dates that fell wholly after $3000 \mathrm{cal}$ вС (at 2 sigma, using the probability calibration method) were not included, while those sites with radiocarbon dates which fell partly before this point were included. Whilst it was always our intention to include Late Mesolithic sites within this study, there were so few dated sites of that period that, in reality, our start point was usually the presence of any Neolithic things or practices. The well-discussed issue of a general absence of Late Mesolithic sites with potential for dating in Britain and Ireland in most regions is a significant problem, but one which is very difficult to resolve. As the title of our paper acknowledges, while we are interested in the Mesolithic-Neolithic transition, our primary focus here in terms of site-based radiocarbon dating has been the Early Neolithic. We also fully acknowledge that a geographically wider-ranging study, which incorporated the adjacent coastal regions in mainland England, Ireland, Scotland, and Wales, would have led to a more holistic understanding of the Earliest Neolithic within the western seaways. However, a study of this magnitude and complexity was not feasible within the confines of the broader Stepping Stones project.

All new dates acquired were obtained via the Oxford Radiocarbon Accelerator Unit, whose methods are set out in full within Brock et al. 2010. Details of the sample pre-treatment and measurement processes for all other legacy dates that were incorporated into our models can be found in Appendix S. 3. Calibrated radiocarbon dates have been produced using the Reimer et al. (2013) curve. Calibration and Bayesian modelling has been applied using OxCal v4.2 (Bronk Ramsey 2009a). Ranges in plain text in the text and tables are the result of simple calibration quoted at $95 \%$ confidence using the intercept method (Stuiver \& Polach 1977; Stuiver \& Reimer 1986). The model structure, denoted by the brackets and OxCal Command Query Language v2 (CQL2; Bronk Ramsey 2009a), indicates the algorithms employed. Posterior density estimates are produced from the model applied, and as such they are not absolute but will change depending on the interpretation of the most appropriate treatment of data (Steier \& Rom 2000). These posterior density estimates are calibrated using the probability method and are by convention quoted in italics. A consistent approach was taken to the treatment of measurements on different types of samples. For example, charcoal samples that were not identified to species level could suffer from the 'old wood' effect. Results on such material can give misleadingly old date ranges if account is not made for the age at death offset. In such cases measurements were treated as termini post quos. Measurements on samples of 'sediment' were not included as active likelihoods in the analysis given the complexities of carbon cycling in such material. Details of the site-specific modelling approaches are given below, in Appendix 2, and for the Orkney assemblage in Griffiths (2016).

The full Stepping Stones radiocarbon database and associated OxCal models are provided as supplementary Appendices (S1 \& S2) and are also available via the Archaeology Data Service (doi: 10.5284/1016098).

\section{RESULTS}

In total, the Stepping Stones database contains information relating to 284 radiocarbon determinations from 48 sites (Fig. 3; Table 1; Appendices 1-2 \& S1).

TABLE 1: REGIONAL OVERVIEW OF RADIOCARBON DATES ANALYSED WITHIN THE PRESENT STUDY

\begin{tabular}{lcc}
\hline Island group & No. of dates & No. of sites \\
\hline Channel Islands & 31 & 7 \\
Isles of Scilly & 6 & 1 \\
Isle of Man & 21 & 4 \\
Outer Hebrides & 38 & 10 \\
Orkney & 188 & 26 \\
Total & 284 & 48 \\
\hline
\end{tabular}


As Table 1 and Figure 3 clearly show, and as we discuss at various points throughout the remainder of the paper, the different island groups have seen far from even coverage in terms of radiocarbon dates.

\section{Channel Islands}

Today the Channel Islands form one group of a larger archipelago strung out along the coast of north-west France (Fig. 3). If a bounding box is drawn around all of the Channel Islands, the total land cover today equates to approximately $213 \mathrm{~km}^{2}$ out of a broader $3400 \mathrm{~km}^{2}$ maritime landscape. The islands are located a minimum distance of $15 \mathrm{~km}$ west of Normandy's Cotentin peninsula, $50 \mathrm{~km}$ north of Brittany, and $90 \mathrm{~km}$ from the south of England. Recent research indicates that Guernsey, Herm, and Sark were separated from mainland France by c. $9000 \mathrm{cal} \mathrm{BC}$, Alderney from c. 7000 cal BC, while Jersey may only have become a full island after $5000 \mathrm{cal}$ BC (Sturt et al. 2013; Garrow \& Sturt forthcoming). Whilst the Channel Islands are now British Crown Dependencies, their geographical proximity to France has contributed to an archaeological record that relates more closely to French sequences throughout later prehistory and beyond (Sebire 2005). The extent of social and material cultural links between the Channel Islands and mainland France prior to the Neolithic is somewhat difficult to ascertain, since very few Late/Final Mesolithic sites are known on the islands (Conneller et al. 2016). The Channel Islands are well-known for their numerous and impressive Neolithic monuments (Patton 1995). With the exception of a single, somewhat unusual (and potentially very early) tomb at Les Fouaillages, Guernsey (see discussion below), most of these monuments are passage graves which are likely to date from $c$. $4300 \mathrm{cal}$ BC onwards (Schulting et al. 2010; Ghesquière \& Marcigny 2011, 176). The earliest Neolithic presence on the islands - associated with Villeneuve Saint Germain (VSG) 'cordons' style pottery - seems to relate primarily to occupation sites, and is likely to have arrived only slightly later there than the earliest Neolithic material in Normandy, and potentially around the same time as the earliest Neolithic evidence from Brittany, although the chronology of the latter is less well understood (Marcigny et al. 2010; Garrow \& Sturt in press).

The modelling presented here incorporates results from seven Channel Island sites (Figs 4 \& 5; Table 2); the Stepping Stones project obtained new dates for two previously undated sites (L'Erée and L'Ouzière) and additional dates for two more (Le Pinacle and Royal Hotel). Of the sites presented here, three occupation sites (L'Ouzière, L'Erée, and Le Pinacle) and two monuments (Les Fouaillages and Le Déhus) have demonstrably shortlife radiocarbon samples (Table 2). Radiocarbon dates are also available for Royal Hotel and La Hougue Bie, but these were on wood charcoal that was not identified to species level.

Royal Hotel, St Peter Port was excavated under difficult circumstances (Sebire 2011, 195) and as a result the archaeological context of the single sherd of clearly diagnostic VSG 'cordons' pottery from the site was not entirely clear. It appears to have come from a pit or post-hole, just outside a possible postbuilt structure (Sebire 2011, 196). Two pieces of unidentifiable wood charcoal have been dated from the site, both from one of the putative structure's post-holes (F44). The results (OxA-12996 and OxA-28902) are statistically consistent but, falling in the last centuries of the 6th millennium cal BC, are earlier than dates associated with VSG 'cordons' style pottery elsewhere on the Channel Islands (this paper) and on mainland France (Marcigny et al. 2010). It thus seems that either or both of the samples from Royal Hotel probably include an inbuilt age offset (see also Sebire 2011, 253).

The site at L'Ouzière has not been formally excavated, but consists of small collections of pottery and flint along with concentrations of charcoal, apparently in association with peat deposits, eroding out of the foreshore (Patton \& Finlaison 2001, 18-21); this material presumably relates to an occupation site of some sort. We obtained two dates on external charred residue on a particularly diagnostic VSG 'cordons' type sherd (Patton \& Finlaison 2001, fig. 3.4). While acknowledging that there may be issues with both internal and external charred residues - it is possible that external residues could incorporate a fuel-derived 'old wood' effect - we have included the two statistically consistent measurements (OxA-28948, -28949; $\mathrm{T}^{\prime}=0.1 ; \mathrm{T}^{\prime} 5 \%=3.8 ; \mathrm{df}=1$ ) on the external residue in our analysis. These types of radiocarbon samples are often poorly understood chemically, and more work undoubtedly needs to be undertaken on this assemblage. However, there remains the potential that this result is indicative of the age of use of the VSG vessel at L'Ouzière in the very late 6th or early 5 th millennium cal BC, in 5030-4840 cal BC $195 \%$ probability; or $5000-4910$ cal $B \mathrm{~B} 68 \%$ probability; L'Ouzière; Fig. 5). 


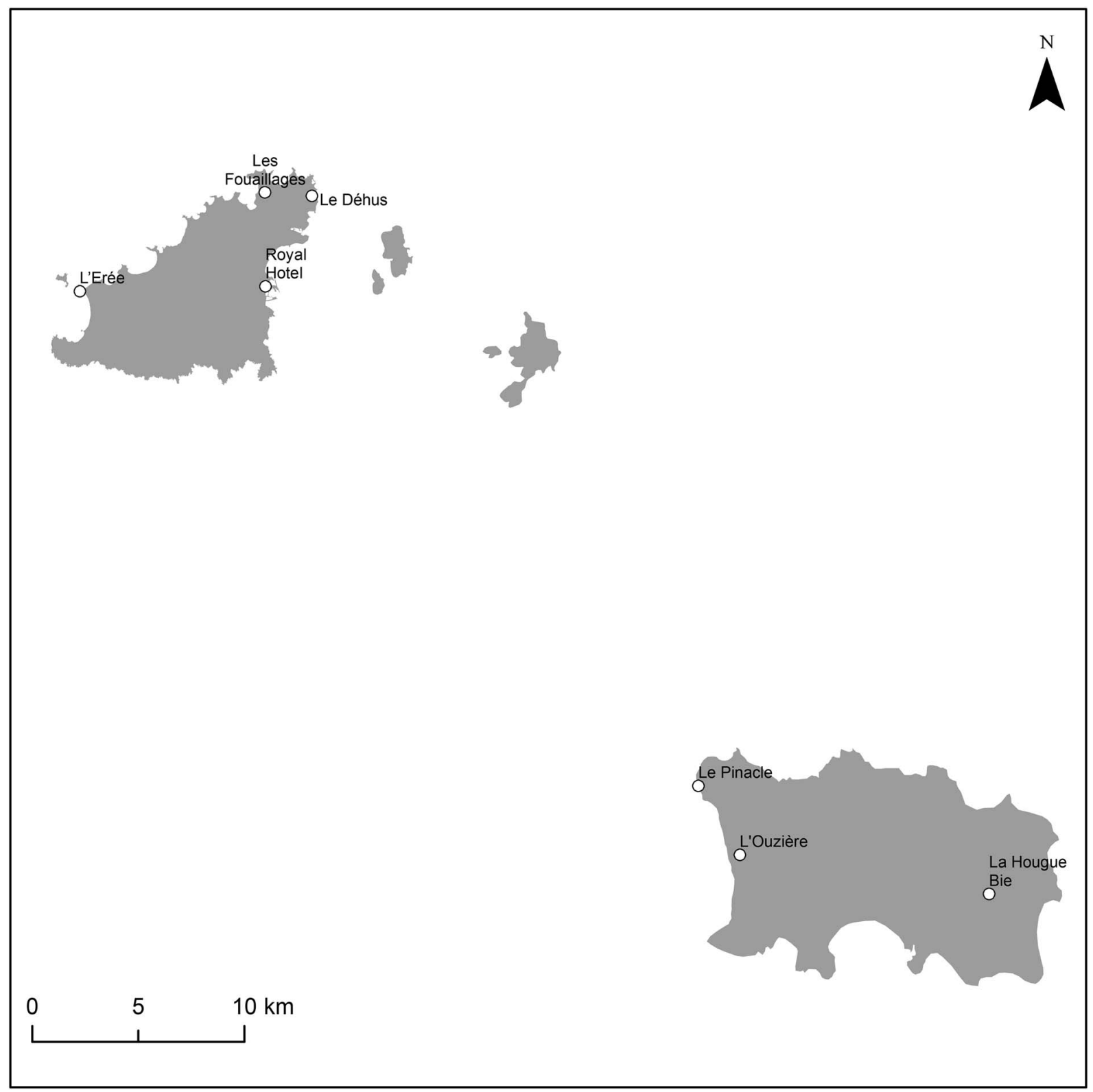

Fig. 4.

Channel Islands: locations of all radiocarbon dated sites

At L'Erée, a date of $4990-4770 \mathrm{cal}$ BC $\quad(95 \%$ probability; or 4910-4800 cal BC $68 \%$ probability; OxA-28670) was obtained also on external charred residue on pottery from our own excavations. The exact character of the archaeology contemporary with this undiagnostic sherd remains unclear - it was recovered from a probably Late Neolithic ditch (Garrow \& Sturt in press). However, other diagnostically VSG materials (a polished stone ring fragment and 'Cinglais' flints) were recovered from the site, adding substantial weight to the suggestion of an early phase of activity there during this period. Five additional dates secured on shortlife charcoal from a series of other features (pits, post-holes, and hearths containing Pinacle-Fouaillages type pottery) on the site suggest a more securely understood second phase of 
THE PREHISTORIC SOCIETY

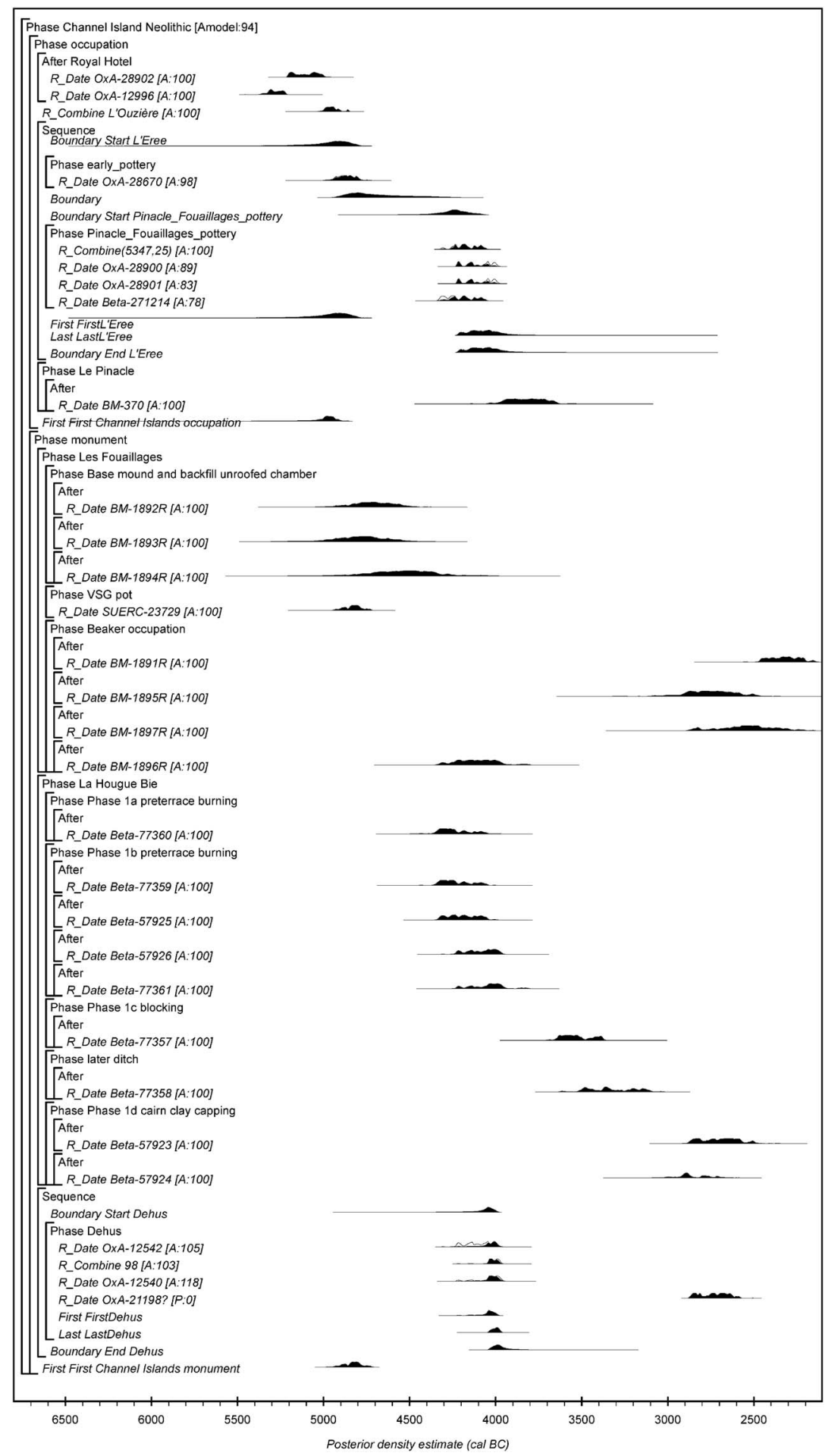

Fig. 5.

Channel Islands: model output 
TABLE 2: SUMMARY OF DATED SITES FROM THE CHANNEL ISLANDS (SEE APPENDICES FOR DETAILS)

\begin{tabular}{|c|c|c|c|c|c|}
\hline Site & Island & Estimate (Fig. 5) & Site type & Summary of site & Reference \\
\hline $\begin{array}{l}\text { Royal Hotel, } \\
\text { St Peter Port }\end{array}$ & Guernsey & $\begin{array}{l}\text { 5210-5000 cal вС (TPQ) (95\% probability; } \\
\text { OxA-28920) } \\
\text { NB: available result not produced on } \\
\text { demonstrably shortlife samples }\end{array}$ & Settlement & $\begin{array}{l}\text { Post-holes (some poss. formed part of } \\
\text { irregular structure), shallow pits, } \\
\& \text { hollows }\end{array}$ & Sebire 2011 \\
\hline L'Ouzière & Jersey & $\begin{array}{l}5030-4840 \text { cal вс (95\% probability; } \\
\text { L'Ouzière) } \\
\text { Weighted mean taken prior to calibration } \\
\text { \& estimating use of pottery }\end{array}$ & Occupation site & $\begin{array}{l}\text { Material observed eroding out of cliff } \\
\text { section - inc. small collections of } \\
\text { pottery \& flint along with } \\
\text { concentrations of charcoal, } \\
\text { apparently associated with peat } \\
\text { deposits }\end{array}$ & $\begin{array}{l}\text { Patton \& } \\
\text { Finlaison } \\
2001\end{array}$ \\
\hline $\begin{array}{l}\text { L'Erée } \\
\text { (Phase 1) }\end{array}$ & Guernsey & $\begin{array}{l}\text { 4990-4780 cal BC }(95 \% \text { probability; } \\
\text { OxA-28670) } \\
\text { Posterior density estimate on measurement } \\
\text { produced on charred residue on pot sherd, } \\
\text { which may date its use }\end{array}$ & $\begin{array}{l}\text { Material } \\
\text { culture } \\
\text { associated } \\
\text { with possible } \\
\text { occupation }\end{array}$ & $\begin{array}{l}\text { Diagnostic Early Neolithic (VSG) } \\
\text { material culture, inc. polished stone } \\
\text { ring, 'Cinglais' flint \& poss Early } \\
\text { Neolithic sherd (latter found within } \\
\text { Late Neolithic ditch) }\end{array}$ & $\begin{array}{l}\text { Garrow \& } \\
\text { Sturt in press }\end{array}$ \\
\hline $\begin{array}{l}\text { Les Fouaillages } \\
\text { (Phase 1b) }\end{array}$ & Guernsey & $\begin{array}{l}\text { 4940-4720 cal BC (95\% probability; } \\
\text { SUERC-23729) } \\
\text { Result produced on sherd of transitional VSG/ } \\
\text { Cerny pottery recovered from site. } \\
\text { No other measurements produced on } \\
\text { demonstrably shortlife samples }\end{array}$ & Tomb & $\begin{array}{l}\text { Early phase of long mound, consisting } \\
\text { of } 2 \text { small stone cairns \& limited kerb }\end{array}$ & Kinnes 1982 \\
\hline $\begin{array}{l}\text { L'Erée } \\
\text { (Phase 2) }\end{array}$ & Guernsey & $\begin{array}{l}4480-4060 \text { cal BC }(95 \% \text { probability; Start } \\
\text { Pinacle_Fouaillages_pottery) } \\
4230-3850 \text { cal BC }(95 \% \text { probability; End } \\
\text { L'Eree) } \\
\text { Boundary parameters estimating start } \& \text { end } \\
\text { of } 2 \text { nd phase activity at site associated with } \\
\text { Pinacle-Fouaillages pottery }\end{array}$ & Settlement & $\begin{array}{l}\text { Stone-lined hearths, post-holes, stake } \\
\text { holes, \& pits }\end{array}$ & $\begin{array}{l}\text { Garrow \& } \\
\text { Sturt in press }\end{array}$ \\
\hline La Hougue Bie & Jersey & $\begin{array}{l}4230-3850 \mathrm{cal} \text { вС }(T P Q) \\
\text { NB: available results not produced on } \\
\text { demonstrably shortlife samples }\end{array}$ & Tomb & Passage grave & $\begin{array}{l}\text { Schulting et al. } \\
\quad 2010\end{array}$ \\
\hline Le Déhus & Guernsey & $\begin{array}{l}4380-3970 \text { cal BC (95\% probability; Start } \\
\text { Dehus) } \\
\text { Boundary parameter estimating start of } \\
\text { activity at site }\end{array}$ & Tomb & Passage grave & $\begin{array}{l}\text { Schulting et al. } \\
2010\end{array}$ \\
\hline Le Pinacle & Jersey & $\begin{array}{l}4050-3630 \text { cal } B C \text { (95\% probability; OxA - } \\
\text { BM 370) } \\
\text { Terminus post quem for activity which may be } \\
\text { associated with Neolithic presence on site }\end{array}$ & Settlement & $\begin{array}{l}\text { Probable stone axe production site } \& \\
\text { associated occupation evidence } \\
\text { (including several hearths \& 'spreads' } \\
\text { of material, pits, etc) }\end{array}$ & $\begin{array}{l}\text { Godfray } \& \\
\text { Burdo } 1949 \\
\text { Patton } 1991\end{array}$ \\
\hline
\end{tabular}


archaeological activity starting 4480-4060 cal вС $(95 \%$ probability; or 4330-4140 cal BC 68\% probability; Start Pinacle_Fouaillages_pottery) and ending in 42303850 cal $B C$ (95\% probability; or 4160-3980 cal BC $68 \%$ probability; End L'Eree; Fig. 5). As noted above, we acknowledge that further work on these types of samples needs to be undertaken, but include this and other results on external residues in this analysis.

At Les Fouaillages, a trapezoidal long mound, four dates had previously been obtained for the Neolithic phases of activity (Patton 1995, 29; Pioffet 2013, 391). Unfortunately, three of these were not produced on demonstrably shortlife samples. The fourth, most recent measurement (SUERC-23729) was obtained on carbonised residue on a pot sherd recovered from the earliest substantial phase (1b) of the monument; this produced a date of $4940-4720 \mathrm{cal}$ BC $(95 \%$ probability; $4900-4780$ cal вС $68 \%$ probability). This phase of the site is associated with transitional VSG/ Cerny pottery (Pioffet 2013), which fits well with the date range indicated. The tomb at Les Fouaillages is essentially unique in terms of its monumental architecture (even including sites on the adjacent mainland), making it difficult to place in typological terms. The date obtained for the initial phases of the site suggest it may be the earliest tomb on the Channel Islands; it is also extremely early in relation to the regional northwest French monument construction sequence, being possibly the same date as the very earliest Carnac mounds in Brittany, for example (Scarre 2011, 92).

The sequence of dates established recently for the Le Déhus passage grave in Guernsey suggest a late 5th millennium date for this monument (Schulting et al. 2010), placing it closely in line with other comparable monuments in north-west France (Ghesquière \& Marcigny 2011, 176; Scarre 2011, 135-70). Dates obtained from the passage grave of La Hougue Bie, Jersey were broadly comparable (Schulting et al. 2010) but not on demonstrably shortlife material.

Le Pinacle, Jersey, presents a complex archaeological sequence, including a probable Neolithic axe production site and associated occupation in its early Pinacle-Fouaillages-associated phase, sealed by Bronze and Iron Age deposits (Godfray \& Burdo 1949; Patton 1995, 29). The single previous radiocarbon result from the site (BM-370) cannot be viewed as reliable as its original context was unclear (Patton 1991, 52), and it cannot be demonstrated to have been produced on shortlife material. All three newlysubmitted samples obtained by the Stepping Stones project - which supposedly related to Neolithic features - produced Late Bronze Age dates, raising considerable further doubts about the contextual security of all material from this site.

There are insufficient results from the Channel Islands for any regional Bayesian modelling. For the settlement sites, there are only two results which are arguably accurate estimates for activity: the measurements on the L'Ouzière and L'Erée sherds. From burial sites, we have only included results from Le Déhus and the estimate on a VSG potsherd from Les Fouaillages as potentially accurate estimates for activity. Despite the wealth of evidence from this region, there are insufficient data to estimate the start of Neolithic activity, and in this case the estimates for the first dated events from the available data have been produced. A number of key points arise from this review of dates from the Channel Islands. First, the earliest Neolithic - represented by the dated VSG 'cordons' pottery from L'Ouzière and the results on sherds from Phase 1 at L'Erée (OxA-28670) and Phase $1 \mathrm{~b}$ at Les Fouaillages (SUERC-23729) - seems to be broadly contemporary with the start of the Neolithic in adjacent mainland regions (Marcigny et al. 2010; Scarre 2011). In this light, it is interesting to observe that the appearance of the earliest Neolithic in Guernsey (which had been an island for several millennia) does not appear to be any later than that in Jersey (which may still have been connected to mainland France at c. $5000 \mathrm{cal} \mathrm{BC}$ ). In this case therefore, the sea does not seem to have represented a barrier or delaying obstacle to the appearance of the earliest Neolithic on the Channel Islands (Garrow \& Sturt forthcoming).

Second, it appears that the earliest Neolithic sites on the Channel Islands may have been settlements rather than monuments, a pattern which reflects the sequence on mainland France where the earliest tombs do not appear until the middle of the 5th millennium BC (Scarre 2011). From the available data associated with occupation sites (Table 2), we estimate that the first dated event associated with a Neolithic presence on the Channel Islands occurred in 5580-4840 cal BC (95\% probability), most probably in 5070-4900 cal BC (68\% probability; First Channel Islands occupation; Fig. 5). Our first estimate for the presence of a Neolithic monument - using very limited active data from Les Fouaillages and Le Déhus - on the Channel Islands occurred in $4940-4730 \mathrm{cal}$ BC $(95 \%$ probability; or 4900-4780 cal BC 68\% probability; First Channel Island monuments; Fig. 5). 


\section{Garrow et al. RADIOCARBON DATING ON ISLANDS WITHIN THE 'WESTERN SEAWAYS' OF BRITAIN}

Third, with regard to the geographical distribution of earliest Neolithic sites, it is notable that all of the dated examples come from the two largest islands, Guernsey and Jersey, which have seen the most research. However, a possible beam-slot structure associated with Cerny 'ancien' pottery was excavated recently on Herm (Chris Scarre pers. comm.), and it seems likely that further substantial excavation on the other islands may well produce 5th millennium sites in addition to known find spots (Garrow \& Sturt forthcoming, table 15-6).

What is notable from discussion of this model is that the majority of the data - with the exception of Le Déhus - derive from measurements on external charred residues. As noted above, both internal and external charred residues are often poorly understood chemically and as a result can produce inaccurate radiocarbon measurements. Without the results produced on charred residues, the earliest activity is indicated by the charcoal measurements associated with the later activity at L'Erée - estimated as 4470 4066 cal BC $(95 \%$ probability; or $4330-4140$ cal $B C$ $68 \%$ probability; Start Pinacle_Fouaillages_pottery) and the estimates for the dates of death of the individuals deposited at Le Déhus, which most probably occurred in the centuries around the turn of the 4th millennium cal $B C$ (4380-3970 cal $B C$ 95\% probability; or 4100-3990 cal BC 68\% probability; Start Dehus).

\section{Isles of Scilly}

The Scilly archipelago today consists of five inhabited islands and numerous smaller uninhabited islets and rocky outcrops (Figs $3 \& 6$ ). They currently have a land area above the $0 \mathrm{~m}$ Ordnance Datum contour of c. $17 \mathrm{~km}^{2}$, out of a broader $173 \mathrm{~km}^{2}$ seascape. The islands are located $45 \mathrm{~km}$ south-west of the current Cornish mainland and $200 \mathrm{~km}$ north-west of France. On a good day, they are fully visible from Cornwall. As a group, they have been separated from the British mainland since c. 11,500 cal BC (Anderson-Whymark et al. 2015, 958). Their specific local topography ensured that they were joined together as a single large island until c. $3000 \mathrm{cal}$ BC when St Agnes was separated; the other main islands remained connected together until the Late Iron Age or Roman period (Anderson-Whymark et al. 2015, 958). The islands' proximity to Cornwall has resulted in both regions having comparable archaeological records in many respects (Johns 2012). Until recently, Mesolithic evidence consisted only of a few find spots (see below); likewise, the Neolithic was predominantly represented by a few stray finds and small artefact scatters. It is possible that the islands were only seasonally visited rather than permanently occupied prior to the Bronze Age (Johns 2012). Two pits containing Hembury-style Early Neolithic pottery were excavated at East Porth, Samson in the 1970s (Johns 2012, 58-60). The distinctive entrance grave tombs found in substantial numbers across Scilly - once thought to be Neolithic have recently been assigned to the Early Bronze Age (Jones \& Thomas 2010). Significantly, our Stepping Stones project excavations at Old Quay, St Martin's in 2013 and 2014 revealed the first major Mesolithic and Neolithic sites on the islands, producing 80 microliths amongst a much larger flint scatter, and Neolithic post-holes, pits, and other occupation-related material (Anderson-Whymark et al. 2015; Garrow \& Sturt in press). The distinctive characteristics of the Old Quay microlith assemblage suggested a somewhat surprising connection between Scilly and northern France/Belgium during the 7th, 6th, or early 5 th millennia cal BC (Anderson-Whymark et al. 2015). Neolithic material from the site demonstrates direct connections with south-west England through imported stone tools (Garrow \& Sturt in press).

No radiocarbon dates associated with Mesolithic or Neolithic archaeological material had previously been obtained from the islands. The pits at East Porth, Samson produced no material suitable for dating, and so the present dating programme focused exclusively on the occupation site at Old Quay, St Martin's (Figs $6 \& 7$; Table 3). The radiocarbon results from Old Quay demonstrate three phases of activity at the site (echoing the material culture recovered there) relating to the Neolithic, the Early Bronze Age, and the Romano-British period; the Mesolithic phase material could not be dated due to an absence of reliably associated organic material. The Neolithic phase archaeologically the most substantial period of activity at the site, characterised by post-holes and pits containing Hembury/South-western Bowl style pottery was associated with six radiocarbon determinations. The site may have witnessed multiple sub-phases of Neolithic occupation (see Garrow \& Sturt in press), but there were no stratigraphic relationships or clear typological differences within the material culture recovered that could be used to inform the model. This is the only site with radiocarbon dates associated with Early Neolithic activity that exists for this region, and therefore the estimate for the start of activity at the site 


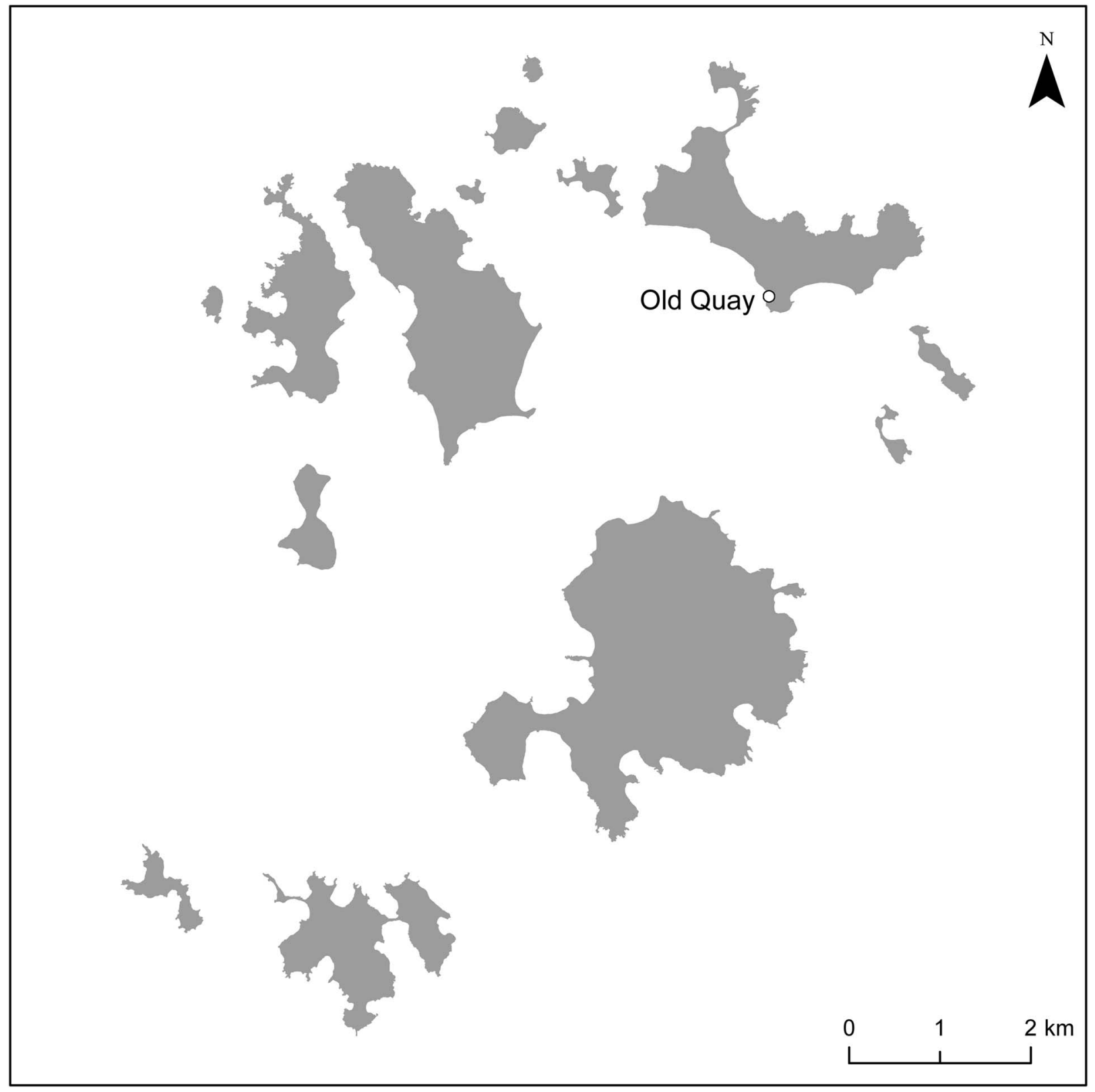

Fig. 6.

Isles of Scilly: location of radiocarbon dated site

also provides the estimate for the start of activity in the region. The radiocarbon measurements obtained suggest that the start of Neolithic activity at Old Quay began in 3460-3040 cal BC (95\% probability; or 3340-3240 cal BC 28\% probability; or 3210-3100 cal BC $40 \%$ probability; Start Old Quay, St Martins) and ended in $3110-2770 \mathrm{cal}$ ВС $(88 \%$ probability; or
3090-2940 cal BC 68\% probability; End Old Quay, St Martins; Fig. 7). These dates are later than those normally associated with Hembury/South-western Bowl style pottery on the mainland, suggesting that the style may have carried on in use for longer on the islands (see Garrow \& Sturt in press for a detailed discussion). Whilst the determinations obtained represent 


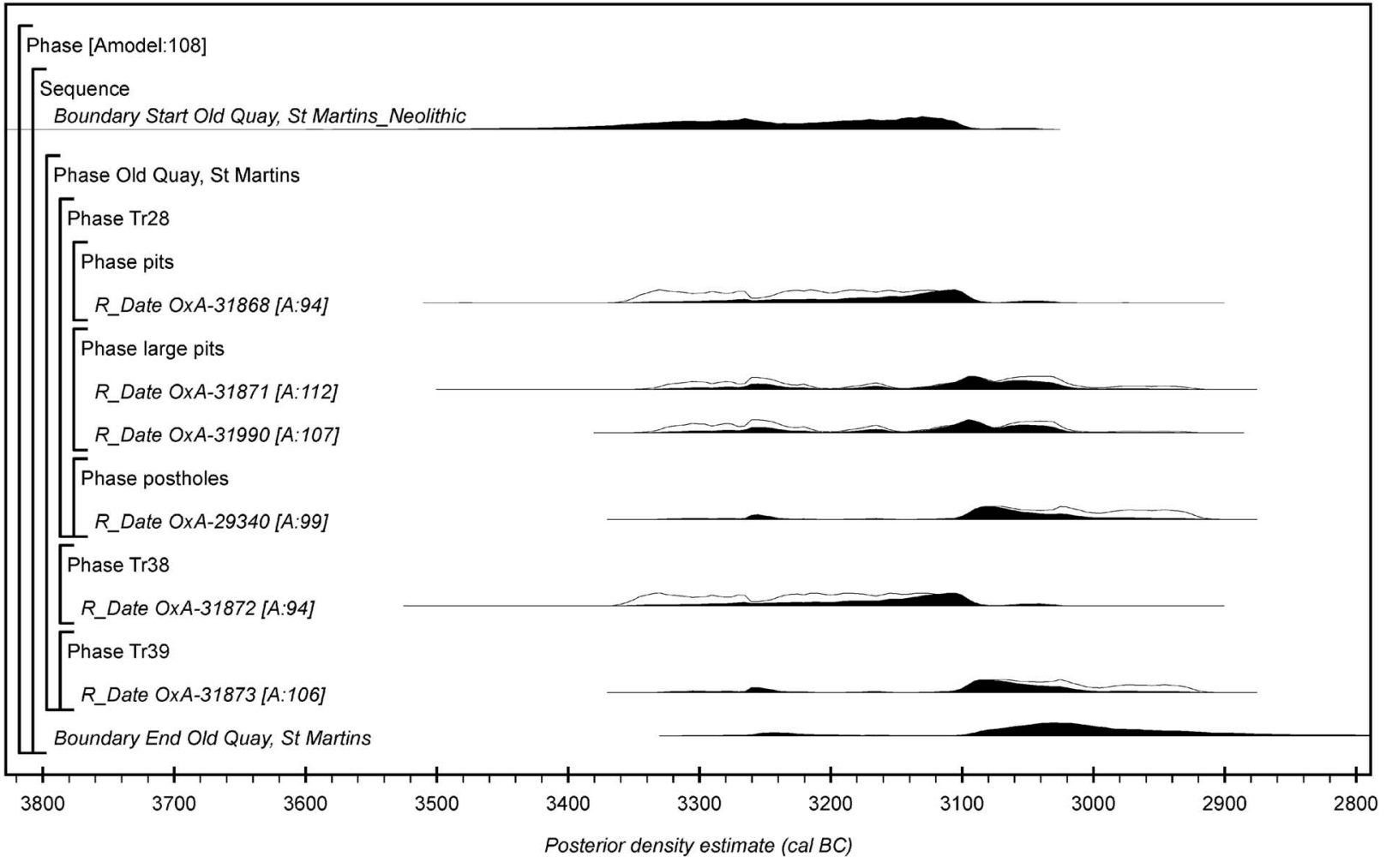

Fig. 7.

Old Quay, Isles of Scilly: model output for Neolithic phase

TABLE 3: SUMMARY OF DATED SITES FROM THE ISLES OF SCILLY (SEE APPENDICES FOR DETAILS)

\begin{tabular}{lccccc}
\hline Site & Island & Estimate (Fig. 7) & Site type & Summary of site & Reference \\
\hline Old Quay & St Martin's & $\begin{array}{l}3460-3040 \text { cal BC (95\% probability; } \\
\text { Start Old Quay, St Martins) } \\
\text { Boundary parameter estimating start of } \\
\text { activity associated with Neolithic } \\
\text { presence on site }\end{array}$ & Settlement & $\begin{array}{c}\text { Pits, post-holes, } \\
\text { hearths, midden }\end{array}$ & Garrow \& \\
& & & \\
& & & \\
\hline
\end{tabular}

an accurate estimate for the earliest Neolithic activity at Old Quay, it remains impossible to determine the chronology of the earliest Neolithic on the Isles of Scilly more broadly at this stage.

\section{Isle of Man}

The Isle of Man, a single large island, covers a total area of $572 \mathrm{~km}^{2}$, extending approximately $52 \times 22 \mathrm{~km}$ overall. It is located in the middle of the Irish Sea, in close proximity to Scotland $(29 \mathrm{~km})$, Ireland $(52 \mathrm{~km})$, England $(57 \mathrm{~km})$, and Wales $(72 \mathrm{~km})$ (Fig. 3). The Isle appears to have separated from the UK mainland sometime between 15,000 and 13,000 years ago (Brooks et al. 2011), with a large intertidal zone providing a possible intermittent connection for another thousand years or so. The island's proximity to both Britain and Ireland has contributed to an archaeological record that, at various times, has had affinities with patterns of change on both landmasses. The Isle of Man has traditionally been viewed as isolated during the Late Mesolithic, especially from Britain (eg, McCartan 2004; Sheridan 2007, 466). In the Neolithic, the island witnessed the construction of chambered and court tombs, some of which contain 
TABLE 4: SUMMARY OF DATED SITE FROM THE ISLE OF MAN (SEE APPENDICES FOR DETAILS)

\begin{tabular}{|c|c|c|c|c|c|}
\hline Site & Island & Estimate (Whittle et al. 2011, 808) & Site type & Summary of site & Reference \\
\hline Billown & Isle of Man & $\begin{array}{l}4040-3700 \text { cal BC (95\% probability; } \\
\text { start Manx Neolithic) } \\
\text { Boundary parameter estimating start of } \\
\text { activity at Billown (Whittle et al. } \\
\text { 2011) }\end{array}$ & Settlement & $\begin{array}{l}\text { Neolithic pits, } \\
\text { scoops, shafts, } \\
\text { \& possible } \\
\text { post-holes }\end{array}$ & $\begin{array}{l}\text { Darvill 2001; } \\
\text { Whittle et al. } \\
\text { 2011, 553-61 }\end{array}$ \\
\hline
\end{tabular}

'shouldered bowls'/Mull Hill type pottery similar to material found in north-east Ireland and south-west Scotland (Burrow 1997).

The evidence for Neolithic settlement on the island is very limited. The only excavated Early Neolithic occupation site is Billown (Table 4; Darvill 2000; 2001; Whittle et al. 2011, 554-61 \& 808), although material culture has been recovered from another presumed occupation site at Phurt/Port Cranstal (Burrow 1997, 43). Our database contains relevant radiocarbon dates from three further sites: Rhendoo, an excavation producing typologically Late Mesolithic material (McCartan \& Woodman 1994); Ballachrink, a trench containing early 5th millennium cal BC arguably 'cereal-type' pollen (Innes et al. 2003); and King Orry's Grave, a Neolithic tomb (Burrow 1997; Fig. 8). However, all of these were obtained either from old wood or unspecified charcoal samples. Whittle et al. $(2011,808)$ note a further date 'allegedly from below a cist' at Port St Mary, but this was considered too uncertain a context to include.

Unlike all of the other island groups considered in this paper, the Isle of Man was directly included in Gathering Time (Whittle et al. 2011, 553-61 \& 808) and thus - as no relevant new evidence has been recovered since - it is necessary here only to repeat briefly the results of models for the island presented therein. Whittle et al. suggested that there remains much work to do before the Mesolithic-Neolithic transition there is understood and pointed out that none of the tombs on the island are accurately dated and that the identification of early cereal-type pollen at Ballachrink can be viewed as highly problematic. They ended their discussion by stating that 'further dating of short-life material firmly associated with Early Neolithic activity on Mann is obviously highly desirable' (Whittle et al. 2011, 808). As with our model for Scilly, their model for the island ultimately had to be derived from a single site, Billown, where the earliest evidence for Neolithic things and practices is 4040 3700 cal BC $(95 \%$ probability; Whittle et al. 2011,

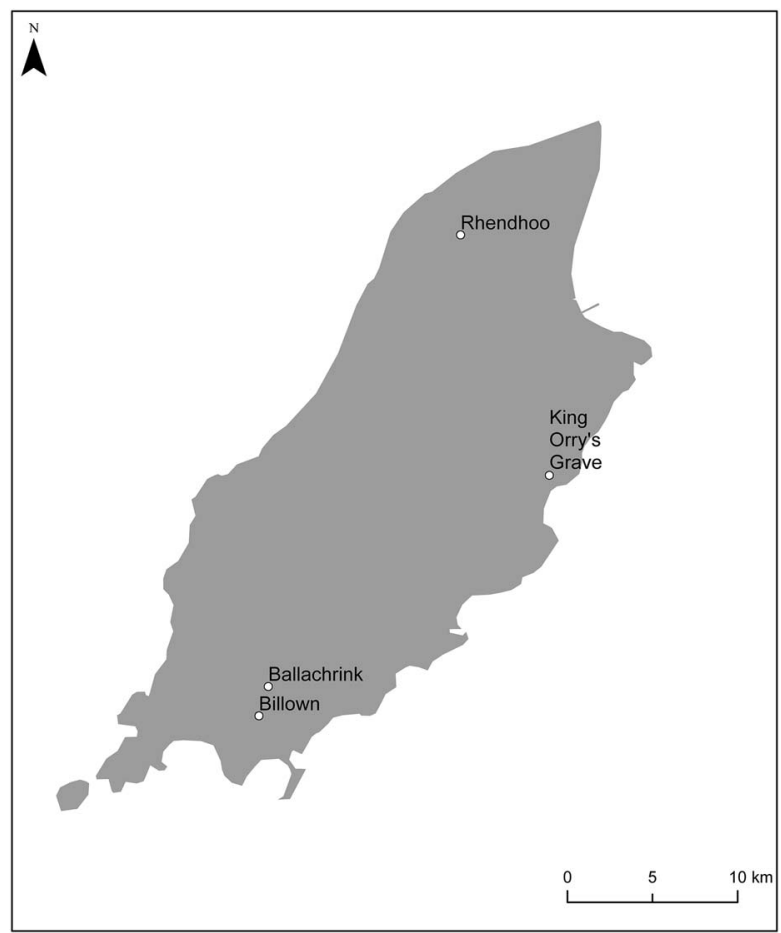

Fig. 8 .

Isle of Man: locations of all radiocarbon dated sites

808, fig. 14.148; Start Manx Neolithic; or 39053725 cal вС $68 \%$ probability; ibid., 808).

\section{Outer Hebrides}

The Outer Hebrides (or Eilean Siar/Western Isles) today comprise 15 inhabited islands and more than 50 uninhabited islands forming an extensive chain off the north-west coast of Scotland (Fig. 3). They currently cover an area of $c .3070 \mathrm{~km}^{2}$ in total, extending across an area of approximately $210 \times 47 \mathrm{~km}$. The islands are located a minimum distance of $23 \mathrm{~km}$ west of the Inner Hebridean island of Skye, and approximately $47 \mathrm{~km}$ west of the Scottish mainland. During the Devensian (last) glaciation, the Outer Hebrides were joined to 


\section{Garrow et al. RADIOCARBON DATING ON ISLANDS WITHIN THE 'WESTERN SEAWAYS' OF BRITAIN}

mainland Scotland via the British-Irish ice sheet. As this melted, the physical connection was lost with the deep waters of the Minch giving them island status by c. 13,000 cal BC (Brooks et al. 2011). Known Mesolithic archaeology from the Outer Hebrides is rare in comparison to the widespread and well-researched material from the Inner Hebrides. However, several new sites have been identified and excavated in recent years (Bishop et al. 2014 \& references within), suggesting at least a limited Mesolithic presence on the islands throughout much of the period. The islands are well-known for their impressive Neolithic burial monuments (Armit 1996; Henley 2003). In comparison to the island groups discussed so far within this paper, the Neolithic settlement evidence is relatively substantial, with the remains of often complex sequences of stone-built house walls and hearths, postholes, and other occupation-related features known from several sites (see Armit 1996; Henley 2003 \& Garrow \& Sturt in press for summaries).

The modelling presented here incorporates 13 Outer Hebrides sites, five of which were newly dated as part of the Stepping Stones project (Figs $9 \& 10$; Table 5). All of the sites with radiocarbon dates from the Outer Hebrides probably represent occupation sites; none of the results derives from a location that is clearly identifiable as a monument. Eight of the dated sites indicate activity in the first half of the 4th millennium cal BC. While there are more data from this region than the Isle of Man or the Isles of Scilly, the archaeological record of the earliest Neolithic in this region is still relatively poorly understood. Those sites with multiple early radiocarbon dates have issues with sample association, and it is as yet unclear that the earliest Neolithic activity is well-sampled. With this in mind, estimates for individual site chronologies have been produced, and estimates for the first and last dated events for the regional Neolithic as a whole have been made from the extant data. We suggest that the individual site estimates, and the first dated event for which we currently have evidence, are more informative about the nature of the Early Neolithic in the Outer Hebrides than a necessarily imprecise estimate for the start of the regional Neolithic as a whole.

At Dunsabroc, Neolithic material (including charred plant remains) is present, apparently redeposited in Iron Age deposits (McHardy et al. 2009, 90-6). The Neolithic results are modelled as representing a phase of activity, probably beginning in $3860-3430 \mathrm{cal} \mathrm{BC}$
(95\% probability; or 3660-3530 cal BC 68\% probability; Start Dunasbroc; Fig. 10).

At Eilean Domhnuill, 14 published radiocarbon results are associated with Neolithic activity; these can be tied into the multi-phase developmental stratigraphic model for the site. The results are in the process of being analysed by Ian Armit, who has kindly allowed an initial model to be presented here. The nature of the site - with phases of inundation and multiple archaeological phases - has resulted in an important and complex sequence. The initial model suggests the earliest Neolithic sampled activity occurred in 3720-3510 cal BC $195 \%$ probability; or 36603560 cal вС 68\% probability; Start Eilean Dornhuill). As noted, the radiocarbon results from Eilean Domhnuill are the subject of ongoing analysis, and this initial model may be revised.

At Allt Chrisal site T26A, three radiocarbon results were produced on samples of birch charcoal associated with an area interpreted as a Neolithic working area. The first dated sample in the site stratigraphic sequence from Allt Chrisal suggests the first Neolithic activity on the site occurred in 3730-3500 cal BC $194 \%$ probability; or 3670-3530 cal BC 68\% probability; GU-3922; Fig. 10).

Of the sites from which radiocarbon samples were submitted as part of the Stepping Stones project, three related to three separate, recently discovered loch sites on the Isle of Lewis (Sheridan et al. 2014): Loch Bhorghastail, Loch Arnish, and Loch an Duna. All three results were produced on internal residues from Neolithic Hebridean-style pottery vessels. Loch Bhorghastail was the earliest of the three, calibrating to $3640-3380 \mathrm{cal}$ вс (95\% confidence; OxA-28954; Fig. 10). The other two sites were also dated to the middle centuries of the 4th millennium (see Table 5).

At Bharpa Carinish, a probable occupation site, five radiocarbon results had previously been produced on birch and hazel charcoal from hearth fills. There is limited information with which to model these results, so the output is unfortunately imprecise, nevertheless the estimate for the start of activity at the site is 3630 2930 cal BC $195 \%$ probability; or $3350-3030$ cal BC $68 \%$ probability).

As a result of the Stepping Stones project, three additional dates for the islet site of Eilean an Tighe, North Uist, were secured (all on internal food residues from Hebridean Neolithic pottery) in addition to the single existing result. These suggest that Neolithic activity there began in 3530-3360 cal BC 


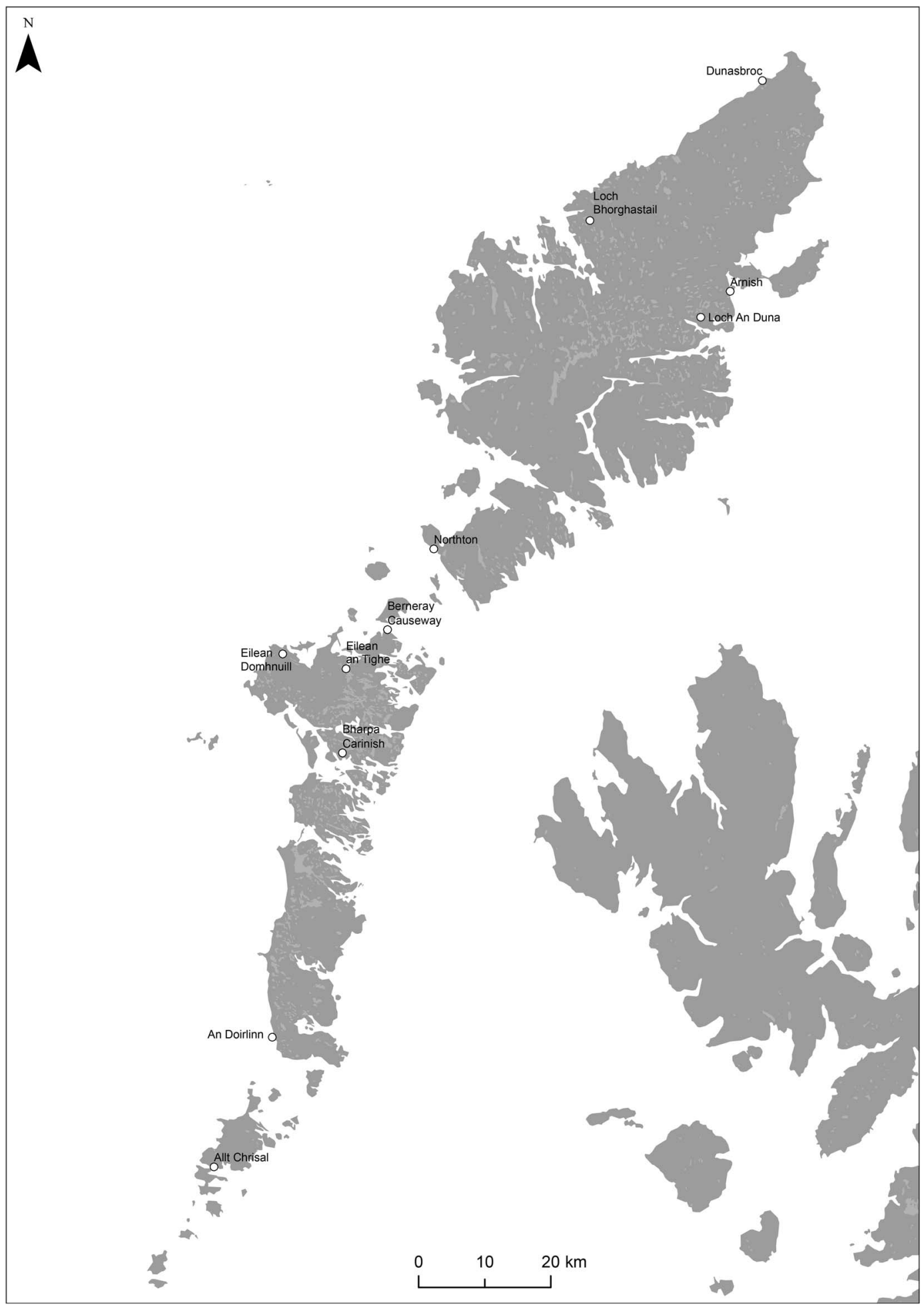

Fig. 9.

Outer Hebrides: locations of all radiocarbon dated sites 


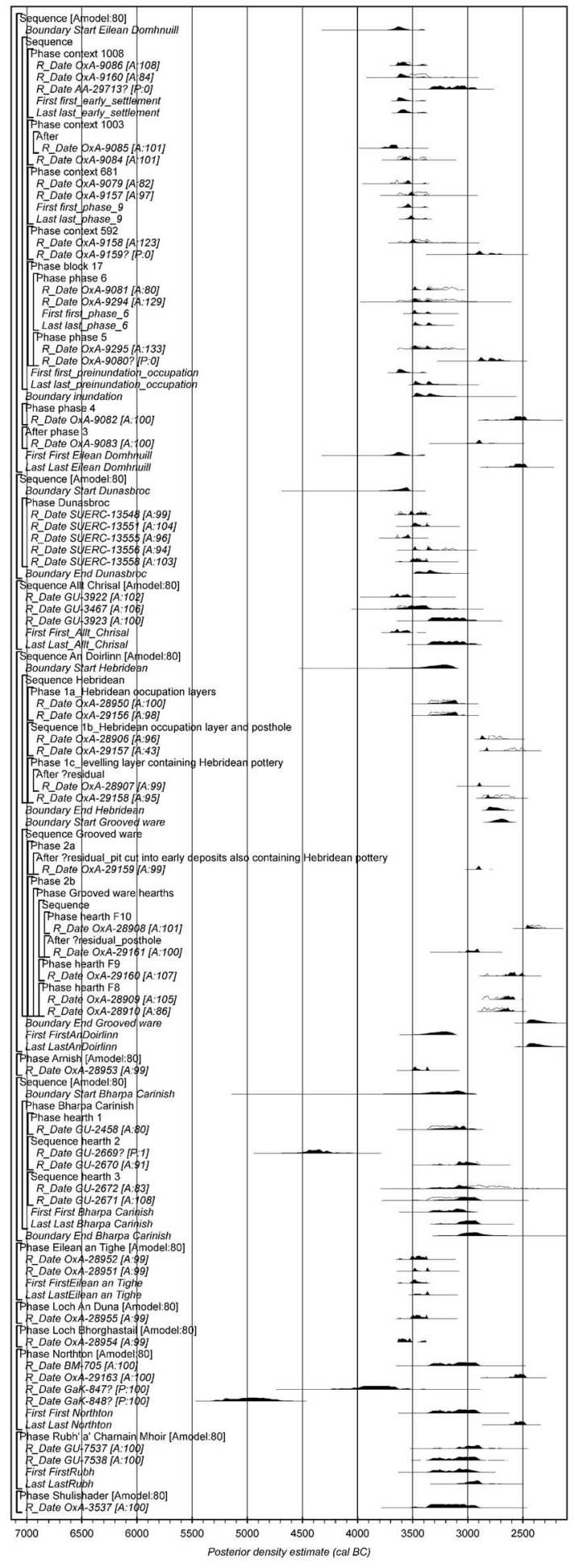

Fig. 10.

Outer Hebrides: model output
(94\% probability; or $3520-349016 \%$ probability; or 3470-3370 cal BC 52\% probability; OxA-28952).

As a result of the Stepping Stones project's excavations at An Doirlinn, 12 samples were submitted from stratigraphically related deposits. Here, activity in site phase $1 \mathrm{a}$, associated with Hebridean pottery, is estimated to have begun in 3530-3100 cal BC $195 \%$ probability; or 3340-3140 cal BC 68\% probability; Start Hebridean; Fig. 10). The earliest deposits from phase 1a produced no dateable material, so it is possible that the estimate for the start of Neolithic activity represents a terminus ante quem for the earliest phase (see Garrow $\&$ Sturt in press for further discussion).

Details of the three remaining sites - Shulishader, Northton, and Rubh' a' Charnain Mhoir - all of whose date ranges fell within the later 4th millennium cal $\mathrm{BC}$, are provided in Table 5 and Appendix 2.

Several key points arise from this consideration of all known dated Early Neolithic sites from the Outer Hebrides. First, it appears to be the case that the earliest Neolithic on the islands did not arrive substantially later than it did on the adjacent mainland. Notably, that region is in itself not at all well-dated, and - being located north of the Great Glen - not considered in detail in Gathering Time. However, as far as it is possible to infer from the extrapolated model presented there, it probably witnessed the arrival of the Neolithic around c. 3800-3700 cal BC (Whittle et al. 2011, fig. 15.8). Second, it is very important to note that none of the dated sites discussed in this section are burial monuments - all are settlements, or material most likely to be derived from settlement contexts of some sort. There are no existing radiocarbon dates from tombs, mainly due to the fact that acidic soils mean that bone is not preserved within them. A targeted programme in future could, however, potentially make use of surviving charcoal from these sites. In contrast to the picture for the Channel Islands, where it is likely that the earliest Neolithic sites are actually settlements (not burial monuments), in the Outer Hebrides it is simply not possible to say at this stage.

\section{Orkney}

The Orkney archipelago today comprises 20 inhabited islands and more than 50 additional uninhabited islands off the north-east coast of Scotland (Fig. 3). They currently cover an area of $990 \mathrm{~km}^{2}$ in total, extending across an area of $86 \times 47 \mathrm{~km}$. The islands are located a minimum distance of $10 \mathrm{~km}$ north of the 
TABLE 5: SUMMARY OF DATED SITES FROM THE OUTER HEBRIDES (SEE APPENDICES FOR DETAILS)

\begin{tabular}{|c|c|c|c|c|c|}
\hline Site & Island & Estimate (Fig. 10) & Site type & Summary of site & Reference \\
\hline Dunasbroc & Lewis & $\begin{array}{l}3860-3430 \text { cal BC }(95 \% \text { probability; Start } \\
\text { Dunasbroc) } \\
\text { Boundary parameter estimate for start of Neolithic } \\
\text { activity at site }\end{array}$ & $\begin{array}{l}\text { Possible } \\
\text { occupation site }\end{array}$ & $\begin{array}{l}\text { Possible occupation site (single } \\
\text { post-hole \& pottery/flint/quartz, } \\
\text { but latter not in situ) }\end{array}$ & $\begin{array}{l}\text { McHardy et al. } \\
2009\end{array}$ \\
\hline Eilean Domhnuill & $\begin{array}{l}\text { North } \\
\text { Uist }\end{array}$ & $\begin{array}{l}3720-3510 \text { cal BC }(95 \% \text { probability; start Eilean } \\
\text { Dornhuill) } \\
\text { Boundary parameter estimate for start of Neolithic } \\
\text { activity at site }\end{array}$ & Settlement & $\begin{array}{l}\text { Islet settlement with multi-phase } \\
\text { buildings, hearths, post-holes, } \\
\text { large amounts of material } \\
\text { culture, etc. }\end{array}$ & Armit 2003 \\
\hline Allt Chrisal & Barra & $\begin{array}{l}3730-3500 \text { cal } B C(94 \% \text { probability; GU-3922) } \\
\text { Earliest radiocarbon posterior density estimate } \\
\text { associated with Neolithic activity on site, estimate } \\
\text { for first activity associated with Neolithic presence } \\
\text { at site }\end{array}$ & Settlement & $\begin{array}{l}\text { Multi-phase buildings, hearths, } \\
\text { post-holes, large amounts of } \\
\text { material culture, etc. }\end{array}$ & $\begin{array}{l}\text { Branigan \& Foster } \\
\quad 1995\end{array}$ \\
\hline Loch Bhorghastail & Lewis & $\begin{array}{l}3640-3500 \text { cal BC ( } 82 \% \text { probability; OxA-28954) } \\
\text { Calibrated radiocarbon date from the site }\end{array}$ & $\begin{array}{l}\text { Material culture } \\
\text { associated with } \\
\text { probable } \\
\text { settlement }\end{array}$ & $\begin{array}{l}\text { Material recovered from loch bed, } \\
\text { likely to be associated with islet } \\
\text { settlement }\end{array}$ & $\begin{array}{l}\text { C. Murray \& } \\
\text { A. Sheridan pers. } \\
\text { comm. }\end{array}$ \\
\hline Bharpa Carinish & $\begin{array}{l}\text { North } \\
\text { Uist }\end{array}$ & $\begin{array}{l}3630-2930 \text { cal BC }(95 \% \text { probability; Start Bharpa } \\
\text { Carinish) } \\
\text { Boundary parameter estimate for start of Neolithic } \\
\text { activity at site }\end{array}$ & $\begin{array}{l}\text { Occupation } \\
\text { features }\end{array}$ & $\begin{array}{l}3 \text { hearths, spreads of ash/charcoal, } \\
\text { fragment of stone wall, } \\
\text { post-holes }\end{array}$ & Crone 1993 \\
\hline Eilean an Tighe & $\begin{array}{l}\text { North } \\
\text { Uist }\end{array}$ & $\begin{array}{l}3530-3360 \text { cal вс (94\% probability; OxA-28952) } \\
\text { Earliest radiocarbon measurement from site, } \\
\text { estimate for first activity associated with Neolithic } \\
\text { presence at site }\end{array}$ & Settlement & $\begin{array}{l}\text { Islet settlement with multi-phase } \\
\text { buildings, hearths, post-holes, } \\
\text { large amounts of material } \\
\text { culture, etc. }\end{array}$ & Scott 1951 \\
\hline An Doirlinn & $\begin{array}{l}\text { South } \\
\text { Uist }\end{array}$ & $\begin{array}{l}3530-3100 \text { cal } B C(95 \% \text { probability; Start Hebridean) } \\
\text { Boundary parameter estimate for start of activity } \\
\text { at site associated with use of Hebridean ware }\end{array}$ & Settlement & $\begin{array}{l}\text { Multi-phase buildings, hearths, } \\
\text { post-holes, large amounts of } \\
\text { material culture, etc. }\end{array}$ & $\begin{array}{l}\text { Garrow \& Sturt in } \\
\text { press }\end{array}$ \\
\hline Loch Arnish & Lewis & $\begin{array}{l}3520-3420 \text { cal BC ( } 67 \% \text { probability) or } 3390- \\
3340 \text { cal BC ( } 29 \% \text { probability; OxA- } 28953) \\
\text { Calibrated radiocarbon date from site }\end{array}$ & $\begin{array}{l}\text { Material culture } \\
\text { associated with } \\
\text { probable } \\
\text { settlement }\end{array}$ & $\begin{array}{l}\text { Material recovered from loch bed, } \\
\text { likely to be associated with islet } \\
\text { settlement }\end{array}$ & $\begin{array}{l}\text { C. Murray \& } \\
\text { A. Sheridan pers. } \\
\text { comm. }\end{array}$ \\
\hline Loch an Duna & Lewis & $\begin{array}{l}3520-3360 \text { cal BC (95\% probability; OxA-28955) } \\
\text { Calibrated radiocarbon date from site }\end{array}$ & $\begin{array}{l}\text { Material culture } \\
\text { associated with } \\
\text { probable } \\
\text { settlement }\end{array}$ & $\begin{array}{l}\text { Material recovered from loch bed, } \\
\text { likely to be associated with islet } \\
\text { settlement }\end{array}$ & $\begin{array}{l}\text { C. Murray \& } \\
\text { A. Sheridan pers. } \\
\text { comm. }\end{array}$ \\
\hline Shulishader & Lewis & $\begin{array}{l}3380-2900 \mathrm{cal} \text { вс (95\% confidence; OxA-3537) } \\
\text { Calibrated radiocarbon date from site }\end{array}$ & Material culture & $\begin{array}{l}\text { Wooden axe haft \& stone axe } \\
\text { found preserved in peat }\end{array}$ & $\begin{array}{l}\text { Canmore ID } \\
71061\end{array}$ \\
\hline Northton & Harris & $\begin{array}{l}3340-2900 \text { вс вс (95\% probability; BM-705) } \\
\text { Calibrated radiocarbon date from Neolithic phase } \\
\text { of site }\end{array}$ & Midden & Midden, possible structure & $\begin{array}{l}\text { Simpson et al. } \\
\quad 2006\end{array}$ \\
\hline $\begin{array}{l}\text { Berneray } \\
\text { Causeway/ } \\
\text { Rubh' a' } \\
\text { Charnain Mhoir }\end{array}$ & $\begin{array}{r}\text { North } \\
\text { Uist }\end{array}$ & $\begin{array}{l}3340-2890 \text { cal вс (95\% probability; GU-7538) } \\
\text { Earliest calibrated radiocarbon date from site } \\
\text { Estimate for first dated event from site }\end{array}$ & $\begin{array}{l}\text { Occupation } \\
\text { features }\end{array}$ & $\begin{array}{l}\text { Irregular large pit, large amounts } \\
\text { of pottery, possible stone wall }\end{array}$ & $\begin{array}{l}\text { Downes \& } \\
\quad \text { Badcock } 1998\end{array}$ \\
\hline
\end{tabular}




\section{Garrow et al. RADIOCARBON DATING ON ISLANDS WITHIN THE 'WESTERN SEAWAYS' OF BRITAIN}

Scottish mainland. Orkney was also connected to mainland Scotland by the Devensian British-Irish ice sheet, but as it melted became established as an island due to the deep channel of the Pentland Firth, separating it from mainland Scotland by $c .13,000 \mathrm{cal}$ BC. Thus although considerable palaeogeographic change has occurred over the Holocene (Sturt et al. 2013), for the purposes of this paper they have always been islands.

A Mesolithic presence on the islands was recognised relatively recently (Saville 2000). Surface collection and investigation of museum and private collections over the past 15 years or so have located further Mesolithic material (Wickham-Jones \& Firth 2000; Cantley 2005; Richards 2005, 11-14) and a total of 51 probable Mesolithic sites have now been identified (data collected by Hugo Anderson-Whymark). Microliths were recovered from the body of a Bronze Age mound at Long Howe, Tankerness (Wickham Jones \& Downes 2007), while recent work at Links House, Stronsay, has produced the most impressive Mesolithic site recovered to date - a lithic scatter associated with groups of cut features, including timber structures (Lee \& Woodward 2009) - suggesting that other substantial sites may await discovery.

The Neolithic of Orkney is extremely well-known, having produced some of the best-preserved Neolithic settlements in Europe, along with a substantial and equally impressive monumental record. The Early Neolithic is characterised by round-based bowl pottery (including Unstan Ware, also found in the Outer Hebrides) and Orkney-Cromarty cairns. Early Neolithic settlement evidence has become increasingly well understood in recent years, with several excavations producing structures, to add to the very well-known Late Neolithic evidence.

A substantial programme of dating and modelling work relating to Orkney (Griffiths 2016) was recently undertaken as part of Richards and Jones's (2016) publication of their work around the Bay of Firth. We do not want to simply repeat that text here, and so in this section we briefly summarise those results, incorporating consideration of all 26 sites with 4th millennium cal BC radiocarbon dates, two of which (Green, Eday and Braes of Ha'Breck, Wyre) were newly-dated through the Stepping Stones project dating programme (Figs $11 \& 12$; Table 6). Neolithic results from later sites (eg, Skara Brae) are the subject of new analysis and have not been included here (Alasdair Whittle pers. comm.); the approach is outlined in
Griffiths (2016) and provides a robust estimate for the timing of the start of the Neolithic.

Two additional radiocarbon results were obtained after the production of the Griffiths (2016) model, one from a primary occupation deposit in house 3, Ha'breck (OxA-29602), and OxA-X-2555-50. OxA$\mathrm{X}-2555-50$ has not been included in the model for Orkney as the measurement is not regarded as reliable due to a very low sample starting weight and nonroutine pretreatment method (Tom Higham pers. comm.). OxA-29602 also has not been included in the model for Orkney as the result appears to be too late for its stratigraphic position; the result is statistically inconsistent with the other measurement from the primary occupation of house 3, Ha'Breck (OxA-28861; $\left.\mathrm{t}^{\prime}=4.3 ; \mathrm{T} ' 5 \%=3.8 ; \mathrm{df} 1\right)$, and is younger than measurements from overlying deposits (Griffiths 2016). The chronological model for the Neolithic in Orkney is therefore unchanged from that discussed in Griffiths (2016). In this model, the Neolithic in Orkney - as represented by radiocarbon dates from houses and tombs - probably started in $3730-3480$ cal BC (95\% probability; Start OrkneyNeolithic; Griffiths 2016, fig. 10.2). The first dated event associated with the use of Neolithic houses in Orkney occurred in 3640 3440 cal BC (95\% probability; FirstHouseSite; Griffiths 2016, fig. 10.5-6). The first estimate for activity associated with a Neolithic tomb in Orkney was in 3650 $3430 \mathrm{cal} B C$ (95\% probability) or $3570-3470 \mathrm{cal} B C$ (68\% probability; First chambered cairn; Griffiths 2016, fig. 10.5). Importantly, however, the earliest dated Neolithic evidence from Orkney is a burnt occupation deposit containing significant quantities of charred cereals (Bishop et al. 2009, 63-5) found preserved underneath a Bronze Age barrow at Varme Dale, Evie, Mainland (Jane Downes pers. comm.). This deposit has been dated to 3760-3630 cal BC (Griffiths 2016, 296), although it is important to note that the date was obtained on willow charcoal, not on one of the cereal grains (which can no longer be located in the project archive). While there is a possibility that the cereal grains are intrusive as a result of later Bronze Age activity on the site, this seems unlikely given the deposit's description as a discreet burned assemblage. Direct dates on the cereal remains would of course resolve this discussion. Notably, the deposits at Varme Dale are $100 \%$ likely statistically to pre-date all of the other dated Neolithic sites from the islands (Griffiths 2016, 298).

In discussing the earliest Neolithic evidence from Orkney, it is vitally important to take into account the 


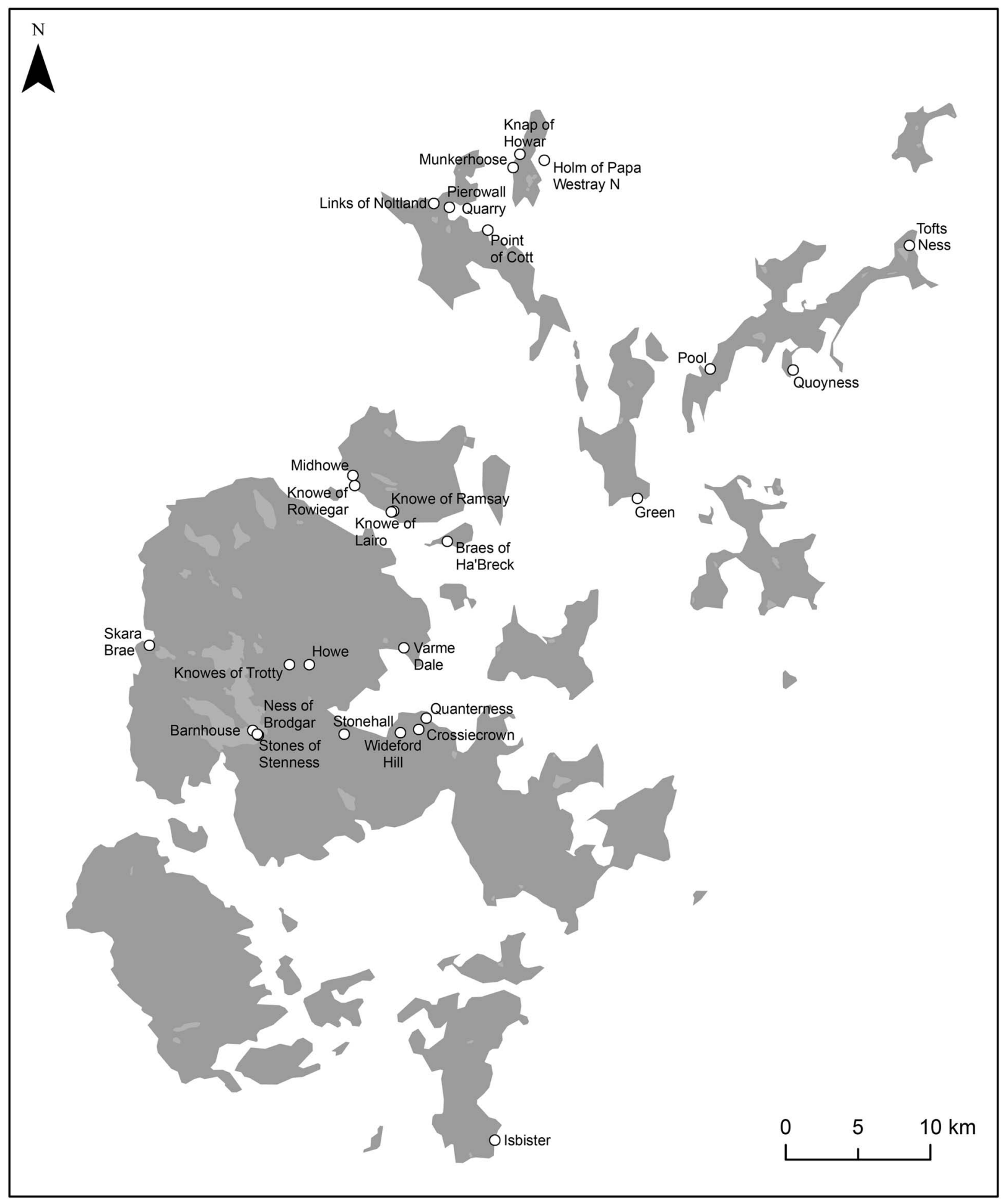

Fig. 11.

Orkney: locations of all radiocarbon dated sites 


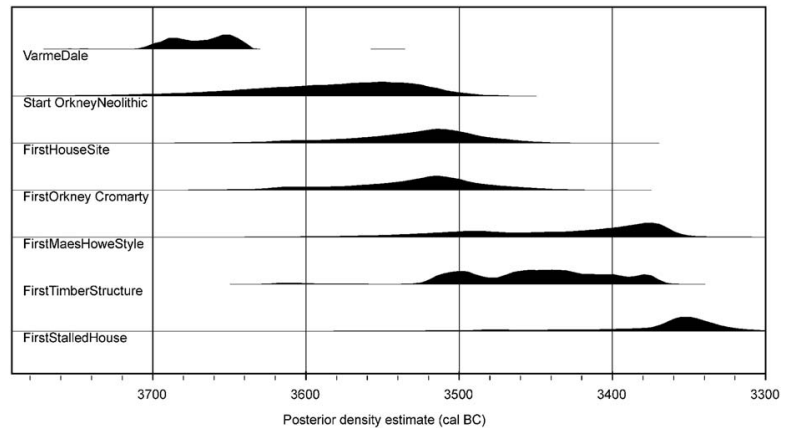

Fig. 12 .

Orkney: model output

fact that, on a number of sites, structures dating to this phase actually post-date midden (or other) deposits containing Neolithic material that are less well understood chronologically. Griffiths has estimated that, as a result, we may be underestimating the start date for the Neolithic in Orkney by 100-200 years (Griffiths 2016, 298); consequently, she suggests that the earliest Neolithic there may date to as early as the 39th or 38th centuries cal BC. (Griffiths 2016, 298) if the Varne Dale activity represents Early Neolithic presence.

It is interesting to note that, as with all of the island groups discussed here, a combined approach to the nature of the dated evidence and the chronological patterning suggests that the earliest Neolithic evidence from the archaeological record in this region may have been undersampled. If this interpretation is robust, the earliest Neolithic evidence from Orkney may not be substantially later there than that from nearby mainland, where it is estimated to have occurred in 3950-3765 cal BC (95\% probability; or $3865-3780$ cal ВС $68 \%$ probability; Start NE Scotland; Whittle et al. 2011, 824).

\section{DISCUSSION: UNDERSTANDING PROCESS, APPRECIATING REPRESENTATIVITY}

The results outlined here represent the first synthetic approach to the chronologies of the earliest Neolithic evidence for the key western seaways zone. At the start of this final discussion, we would like to repeat two key notes of caution raised by others in their considerations of Gathering Time that are also relevant here, along with a third of our own.

The first is Thomas's $(2013,221)$ point that we need to accept the overall model presented by Whittle et al. for the processes of Neolithic transition 'critically and cautiously' due to the various biases in the available data. If that is true of their model, it is also true of those presented here, which are based on fewer (if, overall, still a substantial number of) dates. As we have seen, even in Orkney - the region with by far the most dates in this study - questions remain, especially in relation to the earliest, and thus in this context the most significant, phase of the Neolithic. For the Outer Hebrides and Channel Islands, we have a more limited, yet still reasonable, number and spread of sites. For both the Isle of Man and the Isles of Scilly, however, our understanding is based on a single site. Even at a more local scale, we therefore need to be critical and cautious with regard to the dating and character of the earliest Neolithic in each island group, given the fact that sample sizes are small.

The second note of caution is Sheridan and Pétrequin's (2014, 373) argument that, if there was an Early Neolithic 'strand' in western Britain but it had not been dated, we would not see it within the Gathering Time model. This point sits comfortably alongside the highlighting by Whittle et al. $(2011,846)$ of their own omission of 'key areas' of the mainland from their study, the largest of which were those closest to some of our island groups. We have already discussed the few significant glimpses of known 5th millennium cross-Channel contact. Of these, the Old Quay microliths cannot accurately be dated with certainty, while the significance of both the Magheraboy causewayed enclosure and the Achnacreebeag pot have been fiercely debated (eg, Whittle et al. 2011, 574-85 \& 850-2). Seemingly, the Ferriter's Cove cow bones are the only widely accepted and well-dated sign of 5th millennium contact. This fact brings home the realisation that the very earliest processes of transition that we hope, first, have survived archaeologically, and then, second, to radiocarbon date, are extremely difficult to capture. Given these difficulties, and given the relatively few dates we have for the western seaways zone, it is quite possible that as an archaeological community we have missed other early signs of contact and connectivity. The Thames estuary situation described above, where 37 out of 41 dates within the Gathering Time model were obtained from samples excavated only very recently, reminds us that the picture could be changed significantly with just a few new sites. The Gathering Time model, and our more limited but key addition to it, can indeed only include radiocarbon dated sites. Consequently, if we are to improve our overall understanding of the process(es) of transition at this 
THE PREHISTORIC SOCIETY

TABLE 6: SUMMARY OF KEY ASPECTS OF THE EARLY NEOLITHIC IN ORKNEY (SEE GRIFFITHS 2016 FOR DETAILS)

\begin{tabular}{|c|c|c|}
\hline $\begin{array}{l}\text { Parameter name } \\
\text { (calculated in Griffiths } \\
\text { 2016) }\end{array}$ & $\begin{array}{l}\text { Posterior density estimate unless } \\
\text { otherwise stated ( } 95 \% \text { cal } \mathrm{BC})\end{array}$ & Parameter interpretation \\
\hline VarmeDale & $\begin{array}{l}3710-3630 \text { (calibrated } \\
\text { radiocarbon date) }\end{array}$ & $\begin{array}{l}\text { Weighted mean of the radiocarbon dates from the site taken } \\
\text { prior to calibration }\end{array}$ \\
\hline Start_OrkneyNeolithic & $3730-3480$ & $\begin{array}{l}\text { Boundary across the parameter estimating the start of } \\
\text { Neolithic activity associated with the use of stalled and } \\
\text { timber houses islands, all house sites from the Bay of Firth, } \\
\text { and cairns from across the islands }\end{array}$ \\
\hline FirstHouseSite & $3640-3440$ & $\begin{array}{l}\text { First parameter estimating the first dated event associated } \\
\text { with a timber or stone-built stalled early Neolithic house } \\
\text { on Orkney }\end{array}$ \\
\hline FirstOrkney_Cromarty & $3640-3440$ & $\begin{array}{l}\text { First parameter estimating the first dated event associated } \\
\text { with an Orkney-Cromarty cairn on Orkney }\end{array}$ \\
\hline FirstMaesHoweStyle & $3590-3340$ & $\begin{array}{l}\text { First radiocarbon posterior density estimate associated with } \\
\text { Neolithic activity at a Maeshowe-style monument }\end{array}$ \\
\hline FirstTimberStructure & $3520-3360$ & $\begin{array}{l}\text { First parameter estimating the first dated event associated } \\
\text { with a Neolithic timber structure on Orkney }\end{array}$ \\
\hline FirstStalledHouse & $3520-3290$ & $\begin{array}{l}\text { First parameter estimating the first dated event associated } \\
\text { with the stone-built stalled houses on Orkney }\end{array}$ \\
\hline
\end{tabular}

scale, we need either to excavate and date more sites, and/or improve the way in which we model the process, and/or - even more tricky, and perhaps controversial to some - incorporate an element of typochronology (rather than just radiocarbon dated sites) into our discussions as Sheridan (eg, 2010) suggests.

The third note of caution relates to the substantial bias towards Neolithic sites in our own attempt, and indeed all previous attempts, to understand the chronology of the Mesolithic-Neolithic transition. Sites with diagnostically Mesolithic material dating to the 5th millennium cal $\mathrm{BC}$ are very rare across Britain and Ireland as a whole, except in small regional hotspots such as the Inner Hebrides (Wicks et al. 2014; see also Warren 2007). As Griffiths (2014b) has noted, failure in part to identify terminal Mesolithic sites lies, to some extent, in an emphasis on 'Neolithic' archaeology in the 4th millennium, and on monuments and negative features. Within the western seaways, only a handful of Late Mesolithic sites had been radiocarbon dated. As a result of this current 'view from the Neolithic' understanding, a full picture of the transition cannot be drawn up. For example, elsewhere in regions where Mesolithic material has been better dated, recent work (Griffiths 2014a; 2014b) demonstrates that contemporaneous people in Yorkshire were probably exploiting Mesolithic and Neolithic lifeways in distinct parts of the landscape. In that region, the disarticulation between locations of the latest Mesolithic activity and the earliest Neolithic locations suggests a similar disarticulation in traditions, implying that complex, spatially and temporally variable processes were at work. Complexities such as these in the relationship between 'Mesolithic' and 'Neolithic' need to be drawn out in other regions as well.

Despite these problems in achieving a 'complete' picture of the chronology of the earliest Neolithic within the western seaways zone (and beyond), as a result of our sustained attempt to collate all existing dates and acquisition of many significant new determinations, it has nonetheless been possible to say a great deal - to make significant progress. Broadly speaking, the evidence from the island groups presented here appears to conform well to the macroscale picture of change across Britain and Ireland drawn together in Gathering Time. At the national level, the pattern of spread at least on mainland Britain from south-east England to the northern and western edges of Britain c. 3800-3700 cal BC (Whittle et al. 2011, fig. 15.8) appears broadly to hold true (Fig. 13). In the survey presented in this paper, Orkney is the best-dated island group; it appears to witness the transition c. 3800-3700 cal BC (Griffiths 2016). The Outer Hebrides and the Isle of Man are less well understood, but appear to have seen the arrival of the earliest Neolithic not later than c. 3900 and $3700 \mathrm{cal}$ $\mathrm{BC}$ as well. The one dated site on the Isles of Scilly falls later in the 4th millennium cal $\mathrm{BC}$, but on the basis of a 


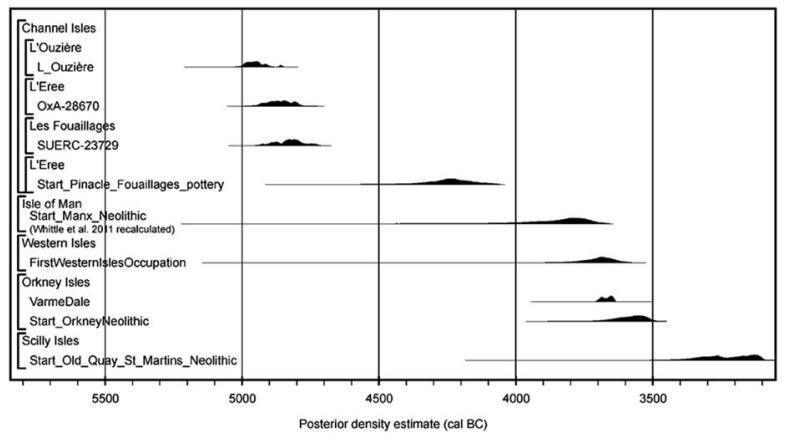

Fig. 13.

Summary of earliest Neolithic dates within the five island groups: model output

single site it is difficult to draw any firm conclusions. As far as it is possible to tell, from the radiocarbon dated evidence alone, those island groups did not act as especially early stepping stones to the Neolithic (although note the discussion above on the potential biases introduced by using only radiocarbon dated sites and the need to incorporate typo-chronological evidence into our wider discussions as well).

Ultimately, each of the island groups investigated has something meaningful to tell us about the chronology of the earliest Neolithic and processes of transition more widely. Moving from north to south, Orkney (as discussed by Griffiths 2016) represents the best-dated island group of the five. In all, the earliest Neolithic there is represented by dates from 26 separate sites, including both tomb and settlement contexts. Nonetheless, questions still remain about our current understanding of the earliest phase of the Neolithic. The earliest dates associated with Neolithic material culture come not from an obvious settlement context or monument, but from material preserved underneath a Bronze Age round barrow at Varme Dale (Griffiths 2016). Interesting comparisons can be drawn here with some of the earliest dated Neolithic contexts in parts of southern England, which have also been midden layers or comparable deposits preserved under later monuments (Whittle et al. 2011, 466). In this case, therefore, the difficulties associated with finding, and then dating, the earliest Neolithic - as discussed above - are made very clear. Equally, the fact that 'the arrival of Neolithic things and practices' was an often complex and ongoing process that occurred over perhaps several centuries, not one event, is made very clear.

The dates secured for the Early Neolithic of the Outer Hebrides, in contrast to Orkney, all come from settlement (or related) contexts. In many cases - and on all of the substantially dated sites - the chronology of these settlements was not straightforward, with complex stratigraphy and potentially mixed contexts usually involved. Moreover, it was not possible to date the earliest phases on both of the otherwise most substantially dated and best-understood sites (An Doirlinn and Eilean Domhnuill). Additionally, in this island group especially, in order to achieve a fuller understanding of all potentially Early Neolithic contexts, additional dates from tombs are required. As bone does not survive well on the islands, this would almost certainly involve new excavation under modern conditions to obtain contextually secure young wood charcoal. Given the clear material links and thus presumed cultural connections between the Outer Hebrides and Orkney during the 4th millennium BC (expressed most clearly in the regions' shared use of Unstan pottery), it is interesting to note the quite different archaeological records and chronologies of change associated with the earliest Neolithic in the two regions - connections around the western seaways may have existed, but they did not straightforwardly lead to similar trajectories of change (these are of course highly complex issues; see Copper 2015 for a more detailed discussion of the relationship between the Outer Hebrides and Orkney).

On the Isle of Man, as Whittle et al. (2011, 808) have already discussed in detail, it is not possible to gain an accurate understanding of the earliest Neolithic from the single well-dated site at Billown. Further evidence, both from other possible settlements and from potentially early tombs, is required. In the case of the Isles of Scilly too, it is impossible to gain an accurate understanding of the earliest Neolithic from a single well-dated site. However, moving beyond that simple point, our work at Old Quay has demonstrated the potential of looking at material culture typochronologies in addition to radiocarbon dates. At Old Quay, the microlith assemblage suggests Late Mesolithic contact between Scilly and northern France/ Belgium. While the assemblage is not (and could not meaningfully be) scientifically dated, typologically it could fall as late as the 5th millennium BC (AndersonWhymark et al. 2015). This reinforces a key point made by Sheridan and Petrequin (2014): the nature of the archaeology at this site - where there is an absence of any good associations between lithic assemblage and potential radiocarbon samples - means that it was not possible to produce scientific dates by these means. 
Old Quay could represent an absolutely crucial - but not radiocarbon datable - site in terms of our understanding of the transition as a whole, providing previously unknown locations and directions of articulation, connection, exchange, and movement across the Channel.

Finally, the Channel Islands - as a direct consequence of their seeing a slightly different material trajectory and somewhat earlier chronology of change compared to all of the other island groups - present us with arguably the most important issue of all to confront. As discussed at the start of the paper, a key background problem in our understanding of the transition in Britain and Ireland as a whole is the approximately 1000 year 'delay' before Neolithic things and practices cross the Channel following their arrival in north-west France. Arguably, the presence of a substantial body of water in between has helped us conceptually - to explain this away. Even if some writers have stressed the considerable porosity of this marine 'barrier' during the 5th millennium BC (see discussion above), the fact that we are dealing with separate modern political entities, which - even more importantly - to our minds are 'separated' by the Channel, has undeniably influenced explanations of the delay. It would arguably have been problematised to a much greater extent if there was no water in between. However, as we have seen, the earliest signs of the Neolithic in the Channel Islands - including Guernsey which had been an island since c. $9000 \mathrm{cal}$ $\mathrm{BC}-$ appear just as early as they do in Brittany and parts of Normandy. The Neolithic appears to have made it across the sea there, despite the fact that at c. $5000 \mathrm{cal}$ BC the distance even from still-connected Jersey to Guernsey would have been directly comparable to that from France to England. Once highlighted in this way, the contrast between the different trajectories that each set of islands (the British Isles and Ireland, and the Channel Islands) witnessed is striking, reawakening us to the potential oddness of the crossChannel 'delay'. It is not our intention here to get into the complex arguments surrounding the causality of the arrival of the Neolithic in southern England. It is also important to acknowledge that comparable 'delays' to the spread of the Neolithic - on land - are seen in certain parts of continental Europe. However, the divergent trajectories highlighted above do suggest to us that, if we are to understand this complex set of processes better, we need to give greater consideration to the different local and regional prehistoric histories of the late 5th millennium on either side of the Channel.
In concluding this paper, we would like to return to a point made at the very beginning: until recently, discussions of the Mesolithic-Neolithic transition had focused primarily on the processes involved, but over the past five to ten years the chronology of the arrival of the earliest Neolithic has come to feature prominently in discussions as well. This has happened largely as a consequence of the substantial radiocarbon dating (and associated modelling) programmes that have taken place. In the broad scale presentation of the evidence put forward by both Whittle et al. (2011) and Collard et al. (2010), broadly speaking, patterning (in terms of radiocarbon dates) has been equated with process (in terms of the geographical spread of the Neolithic) - contours reflecting chronologies are accompanied by arrows representing process or understood to be direct signals of migration (see Fig. 1). In saying this, it should be noted that regional-scale studies of Whittle et al. (2011) presented a more complex and nuanced picture of change. In the study presented here, as a consequence of our comparatively small number of dates spread over a large area, we have been forced to confront more directly the issue of whether the patterns we have identified do indeed accurately reflect the processes seen played out in the later 5th and earlier 4th millennium BC. We have had to consider, very seriously, the biases in our data because they have been made so clear. As a result, more obviously than ever, the fact that we can understand the chronology only of what has been dated has been made manifest. Similarly, the fact that different traditions of research have led to different amounts of excavation in different areas, and thus also to different qualities of understanding of the chronology of the earliest Neolithic in those areas, cannot be avoided.

Intervening between our understanding of past process and our understanding of the chronologies of that process are the contingencies and taphonomies of both the archaeological record and the archaeological endeavour, which bring their own biases to bear on the picture we actually see. That picture - as it currently stands, and as presented in this paper - suggests that the western seaways did not witness significantly earlier Neolithic activity than the adjacent mainland regions or indeed much of northern and western Britain. However, that is only the (incomplete) picture as it currently stands. A few new sites or dates could alter the picture dramatically. In concluding this paper, we do not, however, want to dwell too much 


\section{Garrow et al. RADIOCARBON DATING ON ISLANDS WITHIN THE 'WESTERN SEAWAYS' OF BRITAIN}

on the negative. Moving forwards, it is vitally important that that we are fully aware of our biases, but at the same time we need to take care to balance these out by making the most (if not too much) of any glimpses we get of the underlying, if sometimes well hidden, 'full' picture. Those glimpses will include radiocarbon datable sites and material, but might conceivably also include other more complex, and at times seemingly ambiguous, evidence as well. Whilst the broad-scale narrative constructed using the radiocarbon dated evidence appears to suggest a south-east to north-west process of change (Whittle et al. 2011), other evidence - that sometimes can be dated (eg, the Ferriter's Cove cow bones) but sometimes cannot (eg, the Old Quay microliths) - suggests early contact and connections that do not fit straightforwardly with that model. Consequently, in discussing the MesolithicNeolithic transition in general, it is vitally important a. that we consider those elements which do not fit neatly and so often get lost when broad-scale mapping is undertaken, and $b$. that the full range of archaeological evidence, not just the radiocarbon dated material, is brought to bear in considering this often complex and variable process.

Acknowledgments: We would like to acknowledge the AHRC for their support in funding the broader 'Stepping Stones to the Neolithic' project (AH/I021841/1), of which this research formed one part, and the Society of Antiquaries of London for funding four seasons of excavation in total at L'Erée and Old Quay. The 50 new radiocarbon dates obtained for this project were generously funded by the NERC radiocarbon facility programme. We are very grateful to the staff of the Oxford Radiocarbon Accelerator Unit, University of Oxford, for their careful analytical work on the samples that were dated, especially Tom Higham who offered specialist advice and encouragement at various different stages of the project. We would also like to thank Diana Coles and Mick Miles (BEVARS), Antonia Thomas (University of York), Dan Lee (ORCA) and Rosie Bishop (University of Durham), Alison Sheridan (NMS), Phil de Jersey and Tanya Walls (Guernsey Museums), and Olga Finch and Neil Mahrer (Jersey Heritage) for their assistance in gaining access to and permission to sample new material for dating; Jane Downes (UHI), Colin Richards (UHI), Nick Card (ORCA), Alison Sheridan (NMS), Ian Armit (University of Bradford), Niall Sharples (Cardiff University), and Charlie Johns (Cornwall Council) for related discussions about relevant sites in all five regions; Ceren Kabukcu (University of Liverpool) for her skill and expertise in identifying suitable charcoal samples for dating; Terry Queripel, Steve Walder, Chris Gregory (Duchy of Cornwall), Roddy MacLeod (North Boisdale grazing committee), and Huw Francis (Storas Uibhist) for permission to excavate the three Stepping Stones project sites; the many people (too numerous to list here) who worked with us to excavate those sites; Alison Sheridan, Alasdair Whittle, Oxbow Books, and Elsevier/Journal of Archaeological Science for permission to reproduce the images in Figure 1; Alex Bayliss, Frances Healy, and Alasdair Whittle for their broad support and willingness to provide us with their Gathering Time data (even if we didn't use it all in the end); and finally Anwen Cooper, Alasdair Whittle, and the three anonymous referees for their helpful comments on earlier drafts of this paper.

\section{SUPPLEMENTARY MATERIAL}

To view the supplementary material for this paper please visit https://doi.org/10.1017/ppr.2017.4

\section{BIBLIOGRAPHY}

Anderson-Whymark, H. \& Garrow, D. 2015. Seaways and shared ways: Imaging and imagining the movement of people, objects and ideas over the course of the Mesolithic-Neolithic transition, c. 5000-3500 BC. In H. Anderson-Whymark, D. Garrow \& F. Sturt (eds), Continental Connections: Exploring cross-channel relationships from the Mesolithic to the Iron Age, 59-77. Oxford: Oxbow Books

Anderson-Whymark, H., Garrow, D. \& Sturt, F. 2015. Microliths and maritime mobility: A continental European-style Late Mesolithic flint assemblage from the Isles of Scilly. Antiquity 89, 954-84

Armit, I. 1996. The Archaeology of Skye and the Western Isles. Edinburgh: Edinburgh University Press

Armit, I. 2003. The drowners: Permanence and transition in the Hebridean Neolithic. In Armit et al. 2003, 93-100

Armit, I., Murphy, E., Nelis, E. \& Simpson, D. (eds). 2003. Neolithic Settlement in Ireland and Western Britain. Oxford: Oxbow Books

Armit, I., Swindles, G. \& Becker, K. 2013. From dates to demography in later prehistoric Ireland? Experimental approaches to the meta-analysis of large ${ }^{14} \mathrm{C}$ data-sets. Journal of Archaeological Science 40, 433-8

Bishop, R., Church, M. \& Rowley-Conwy, P. 2009. Cereals, fruits and nuts in the Scottish Neolithic. Proceedings of the Society of Antiquaries of Scotland 139, 47-103

Bishop, R., Church, M. \& Rowley-Conwy, P. 2014. Seeds, fruits and nuts in the Scottish Mesolithic. Proceedings of the Society of Antiquaries of Scotland 143, 9-71

Bowman, S., Ambers, J. \& Leese, M. 1990. Re-evaluation of British Museum radiocarbon dates issued between 1980 and 1984. Radiocarbon 32, 59-79

Branigan, K. \& Foster, P. 1995. Barra: Archaeological research on Ben Tangaval. Sheffield: Sheffield Academic Press

Brock, F., Higham, T., Ditchfield, P. \& Bronk Ramsey, C. 2010. Current pretreatment methods for AMS radiocarbon dating at the Oxford Radiocarbon Accelerator Unit (ORAU). Radiocarbon 52, 103-12 
Bronk Ramsey, C. 2009a. Bayesian analysis of radiocarbon dates. Radiocarbon 51, 337-60

Bronk Ramsey, C. 2009b. Dealing with outliers and offsets in radiocarbon dating. Radiocarbon 51, 1023-45

Brooks, A., Bradley, S., Edwards, R. \& Goodwayn, N. 2011. The palaeogeography of Northwest Europe during the last 20,000 years. Journal of Maps 7, 573-87

Burrow, S. 1997. The Neolithic Culture of the Isle of Man. Oxford: British Archaeological Report 263

Cantley, M. 2005. Mesolithic Orkney fieldwalking project. Discovery and Excavation in Scotland 5, 96-7

Case, H. 1969. Neolithic explanations. Antiquity 43, 176-86

Chiverrell, R., Thorndycraft, V. \& Hoffmann, T. 2011. Cumulative probability functions and their role in evaluating the chronology of geomorphological events during the Holocene. Journal of Quaternary Science 26, $76-85$

Contreras, D. \& Meadows, J. 2014. Summed radiocarbon calibrations as a population proxy: A critical evaluation using a realistic simulation approach. Journal of Archaeological Science 52, 591-608

Collard, M., Edinborough, K., Shennan, S. \& Thomas, M. 2010. Radiocarbon evidence indicates that migrants introduced farming to Britain. Journal of Archaeological Science 37, 866-70

Conneller, C., Bates, M., Bates, R., Schadla-Hall, T., Blinkhorn, E., Cole, J., Pope, M., Scott, B., Shaw, A. \& Underhill, D. 2016. Rethinking human responses to sealevel rise: The Mesolithic occupation of the Channel Islands. Proceedings of the Prehistoric Society 82, 27-71

Copper, M. 2015. The Same but Better: Understanding ceramic variation in the Hebridean Neolithic. Unpublished PhD thesis, University of Bradford

Crawford, O.G.S. 1912. The distribution of Early Bronze Age settlements in Britain. Geographical Journal 40, 184-97

Crawford, O.G.S. 1936. Western seaways. In R. Marett \& L. Buxton (eds), Custom is King: Essays presented to R.R. Marett, 181-200. London: Hutchinson's Scientific $\&$ Technical

Crombé, P. \& Robinson, E. 2014. ${ }^{14} \mathrm{C}$ dates as demographic proxies in Neolithisation models of northwestern Europe: A critical assessment using Belgium and northeast France as a case-study. Journal of Archaeological Science 52, 558-66

Crone, A. 1993. Excavation and survey of sub-peat features of Neolithic, Bronze and Iron Age date at Bharpa Carinish, North Uist, Scotland. Proceedings of the Prehistoric Society 59, 361-82

Cummings, V. \& Harris, O. 2011. Animals, people and places: The continuity of hunting and gathering practices across the Mesolithic-Neolithic transition in Britain. European Journal of Archaeology 14, 361-82

Cunliffe, B. \& de Jersey, P. 2000. Rescue excavations on coastal sites on Guernsey and Herm, 1998 and 1999. Report and Transactions of La Société Guernesiaise 24, 867-944

Darvill, T. 2000. Billown Neolithic Landscape Project, Isle of Man: Fifth Report 1999. Bournemouth/Douglas: School of Conservation Sciences, Bournemouth University/Manx National Heritage
Darvill, T. 2001. Neolithic enclosures in the Isle of Man. In G. Varndell \& P. Topping (eds), Enclosures in Neolithic Europe, 83-9. Oxford: Oxbow Books

Downes, J. \& Badcock, A. 1998. Berneray Causeway: Archaeological watching brief and excavations at the Screvan quarry site and Otternish, North Uist. Unpublished report. Sheffield: ARCUS

Fox, C. 1938. The Personality of Britain, 3 edn. Cardiff: National Museum of Wales

Garrow, D. \& Sturt, F. 2011. Grey waters bright with Neolithic argonauts? Maritime connections and the Mesolithic-Neolithic transition within the 'western seaways' of Britain, c. 5000-3500 BC. Antiquity 85, 59-72

Garrow, D. \& Sturt, F. forthcoming. The MesolithicNeolithic transition in the Channel Islands: Maritime and terrestrial perspectives. Oxford Journal of Archaeology 36

Garrow, D. \& Sturt, F. (eds). in press. Neolithic Stepping Stones: Excavation and survey within the western seaways of Britain, 2008-2014. L'Erée (Guernsey), Old Quay (St Martin's, Isles of Scilly) and An Doirlinn (South Uist). Oxford: Oxbow Books

Ghesquière, E. \& Marcigny, C. (eds). 2011. Cairon. Vivre et mourir au Néolithique. La Pierre Tourneresse en Calvados. Rennes: Presses Universitaires de Rennes

Godfray, A. \& Burdo, C. 1949. Excavations at the Pinnacle, Parish of St Ouen, Jersey (1930-1936). Part I - Neolithic. Annual Bulletin Société Jersiaise 15, 21-100

Griffiths, S. 2014a. Points in time: The chronology of rod microliths. Oxford Journal of Archaeology 33, 221-43

Griffiths, S. 2014b. A Bayesian radiocarbon chronology of the early Neolithic of Yorkshire and Humberside. Archaeological Journal 171, 2-29

Griffiths, S. 2016. Beside the ocean of time: A chronology of Neolithic burial monuments and houses in Orkney. In C. Richards (ed.), The Development of Neolithic House Societies in Orkney, 254-302. Oxford: Windgather

Hedges, R., Tiemei, C. \& Housley, R. 1992. Results and methods in the radiocarbon dating of pottery. Radiocarbon 34, 906-15

Henley, C. 2003. The Outer Hebrides and the Hebridean World During the Neolithic: An island history. Unpublished PhD dissertation, Cardiff University

Innes, J., Blackford, J. \& Davey, P. 2003. Dating the introduction of cereal cultivation to the British Isles: Early palaeoecological evidence from the Isle of Man. Journal of Quaternary Science 18, 603-13

Johns, C. 2012. (ed.) Isles of Scilly Historic Environment Research Framework. Truro: Cornwall Council

Jones, A. \& Thomas, C. 2010. Bosiliack and a reconsideration of entrance graves. Proceedings of the Prehistoric Society 76, 271-96

Kinnes, I. 1982. Les Fouaillages and megalithic origins. Antiquity 56, 26-30

Kinnes, I. 1986. La Néolithisation des Iles Anglo-Normandes. Revue Archéologique de l'Ouest Supplement 1, 9-12

Kinnes, I. 1988. The cattleship Potemkin: the first Neolithic in Britain. In J. Barrett \& I. Kinnes (eds), The Archaeology 


\section{Garrow et al. RADIOCARBON DATING ON ISLANDS WITHIN THE 'WESTERN SEAWAYS' OF BRITAIN}

of Context in the Neolithic and Bronze Age, 2-8. Sheffield: J.R. Collis

Lee, D. \& Woodward, N. 2009. Links House, Stronsay, Orkney (Stronsay parish), excavation. Discovery and Excavation in Scotland 10, 141

Mackinder, H. 1902. Britain and the British Seas. Oxford: Clarendon

Marcigny, C., Ghesquière, E., Juel, L. \& Charraud, F. 2010. Entre Néolithique ancien et Néolithique moyen en Normandie et dans les Iles anglo-normandes: Parcours chronologique. In C. Billard \& M. Legris (eds), Premiers néolithiques de l'Ouest, 28e Colloque interrégional sur le Néolithique, Archéologie et culture, 117-62. Rennes: Presses Universitaires de Rennes

McCartan, S. 2004. The Mesolithic of the Isle of Man: An island perspective. In A. Saville (ed.), Mesolithic Scotland and its Neighbours, 271-83. Edinburgh: Society of Antiquaries of Scotland

McCartan, S. \& Woodman, P. 1994. A later Mesolithic site at Rhendhoo, Jurby. Proceedings of the Isle of Man Natural History \& Antiquarian Society 10, 87-118

McClatchie, M., Bogaard, A., Colledge, S., Whitehouse, N., Schulting, R., Barratt, P. \& McLaughlin, T. 2014. Neolithic farming in north-western Europe: Archaeobotanical evidence from Ireland. Journal of Archaeological Science 51, 206-15

McHardy, I., Barrowman, C. \& Macleod, M. 2009. STAC: The Severe Terrain Archaeological Campaign investigation of stack sites of the Isle of Lewis 2003-2005. Edinburgh: Scottish Archaeological Internet Report 36

Miles, M. 2010. Green, Eday. Report on excavations. Discovery and Excavation in Scotland 11, 119-20

Nakamura, T., Taniguchi, Y., Tsuji, S. \& Oda, H. 2001. Radiocarbon dating of charred residues on the earliest pottery in Japan. Radiocarbon 43, 1129-38

Patton, M. 1991. An Early Neolithic axe factory at Le Pinacle, Jersey, Channel Islands. Proceedings of the Prehistoric Society 57, 51-9

Patton, M. 1995. Neolithic Communities of the Channel Islands. Oxford: British Archaeological Report 240

Patton, M. \& Finlaison, M. 2001. Patterns in a Prehistoric Landscape: The archaeology of St Ouen's Bay, Jersey. Jersey: Société Jersiaise

Patton, M., Rodwell, W. \& Finch, O. 1999. La Hougue Bie, Jersey: A study of the Neolithic tomb, Medieval chapel and Prince's tower, including a report on the 1991-94 excavations. St Helier: Société Jersiaise

Pioffet, H. 2013. Des vases et des îles: Étude de la céramique des Fouaillages à Guernesey dans son contexte (Néolithique ancien et début du Néolithique moyen). In M.-Y. Daire, C. Dupont, A. Baudry, C. Billard, J.-M. Large, L. Lespez, E. Normand \& C. Scarre (eds), Ancient Maritime Communities and the Relationship between People and Environment along the European Atlantic Coasts, 391-400. Oxford: British Archaeological Report S2570

Reimer, P.J., Bard, E., Bayliss, A., Beck, J.W., Blackwell, P.G., Bronk Ramsey, C., Buck, C.E., Chenge, H., Edwards, R.L, Friedrich, M., Grootes, P.M., Guilderson, T.P.,
Haflidason, H., Hajdas, I., Hatté, C., Heaton, T.J., Hoffmann, D.L., Hogg, A.G., Hughen, K.A., Kaiser, K.F., Kromer, B., Manning, S.W., Niu, M., Reimer, R.W., Richards, D.A., Scott, E.M., Southon, J.R., Staff, R.A., Turney, C.S.M. \& Plicht, J. van der. 2013. Intcal 13 and marine13 radiocarbon age calibration curves $0-50,000$ years cal B.. Radiocarbon 55, 1869-87

Richards, C. 2005. Dwelling Among the Monuments: The Neolithic village of Barnhouse, Maeshowe passage grave and surrounding monuments at Stenness, Orkney. Cambridge: McDonald Institute

Richards, C. \& Jones, R. 2016. The Development of Neolithic House Societies in Orkney: Investigations in the Bay of Firth, Mainland, Orkney (1994-2014). Oxford: Windgather

Saville, A. 2000. Orkney and Scotland before the Neolithic period. In A. Ritchie (ed.), Neolithic Orkney in its European Context, 91-100. Cambridge: McDonald Institute

Scarre, C. 2011. Landscapes of Neolithic Brittany. Oxford: Oxford University Press

Schulting, R., Sebire, H. \& Robb, J. 2010. On the road to Paradis: New insights from AMS dates and stable isotopes at Le Déhus, Guernsey, and the Channel Islands Middle Neolithic. Oxford Journal of Archaeology 29, 149-73

Scott, W.L. 1951. Eilean an Tighe: A pottery workshop of the second millennium BC. Proceedings of the Society of Antiquaries of Scotland 85, 1-37

Sebire, H. 2005. The Archaeology and Early History of the Channel Islands. Stroud: Tempus

Sebire, H. 2011. Excavations at the Royal Hotel Site, St Peter Port, Guernsey. La Société Guernesiaise Report and Transactions 27, 190-257

Shennan, S., Downey, S., Timpson, A., Edinborough, K., Colledge, S., Kerig, T., Manning, K. \& Thomas, M.G. 2013. Regional population collapse followed initial agriculture booms in mid-Holocene Europe. Nature Communications 4, 2486

Sheridan, A. 2000. Achnacreebeag and its French connections: Vive the 'auld' alliance. In J. Henderson (ed.), The Prehistory and Early History of Atlantic Europe, 1-16. Oxford: British Archaeological Report S861

Sheridan, A. 2003. French connections I: Spreading the marmites thinly. In Armit et al. 2003, 3-17

Sheridan, A. 2004. Neolithic connections along and across the Irish Sea. In V. Cummings \& C. Fowler (eds), The Neolithic of the Irish Sea, 9-21. Oxford: Oxbow Books

Sheridan, A. 2007. From Picardie to Pickering and Pencraig Hill? New information on the 'Carinated Bowl Neolithic'. In A. Whittle \& V. Cummings (eds), Going Over: The Mesolithic-Neolithic transition in north-west Europe, 441-92. Proceedings of the British Academy 144. Oxford: Oxford University Press

Sheridan, A. 2010. The Neolithization of Britain and Ireland: The 'Big Picture'. In B. Finlayson \& G. Warren (eds), Landscapes in Transition, 89-105. Oxford: Oxbow Books

Sheridan, A. 2012. Review of A. Whittle, F. Healy \& A. Bayliss 'Gathering Time: Dating the Early Neolithic enclosures of Southern Britain and Ireland'. Antiquity 86, 262-4 
Sheridan, A. \& Pétrequin, P. 2014. Constructing a narrative for the Neolithic of Britain and Ireland: The use of 'hard science' and archaeological reasoning. In A. Whittle \& P. Bickle (eds), Early Farmers: The view from Archaeology and Science, 369-90. Oxford: Oxford University Press/British Academy

Sheridan, A., Murray, C., Garrow, D. \& AndersonWhymark, H. 2014. Spectacular Neolithic finds emerge from the lochs of Lewis. PAST 76, 1

Simpson, D., Murphy, E. \& Gregory, R. 2006. Excavations at Northton, Isle of Harris. Oxford: British Archaeological Report 408

Spriggs, M. \& Anderson, A. 1993. Late colonization of East Polynesia. Antiquity 67, 200-17

Steier, P. \& Rom, W. 2000. The use of Bayesian statistics for ${ }^{14} \mathrm{C}$ Dates of chronologically ordered samples: A critical analysis. Radiocarbon 42, 183-98

Stuiver, M. \& Polach, H.A. 1977. Reporting of ${ }^{14} \mathrm{C}$ data. Radiocarbon 19, 355-63

Stuiver, M. \& Reimer, P.J. 1986. A computer program for radiocarbon age calculation. Radiocarbon 28, 1022-30

Sturt, F., Garrow, D. \& Bradley, S. 2013. New models of North West European Holocene palaeogeography and inundation. Journal of Archaeological Science 40, 3963-76

Thomas, A. 2007. The Braes of Ha'breck, Wyre, Orkney (Rousay and Egilsay parish), excavation. Discovery and Excavation in Scotland 8, 143-4

Thomas, J. 2008. The Mesolithic-Neolithic transition in Britain. In J. Pollard (ed.), Prehistoric Britain, 58-89. Oxford: Blackwell

Thomas, J. 2013. The Birth of Neolithic Britain. Oxford: Oxford University Press
Timpson, A., Colledge, S., Crema, E., Edinborough, K., Kerig, T., Manning, K., Thomas, M. \& Shennan, S. 2014. Reconstructing regional population fluctuations in the European Neolithic using radiocarbon dates: A new case-study using an improved method. Journal of Archaeological Science 52, 549-57

Warren, G. 2007. Mesolithic myths. In A. Whittle \& V. Cummings (eds), Going Over: The MesolithicNeolithic transition in north-west Europe, 311-28. Proceedings of the British Academy 144. Oxford: Oxford University Press

Whittle, A., Bayliss, A. \& Healy, F. 2011. Gathering Time: Dating the early Neolithic enclosures of southern Britain and Ireland. Oxford: Oxbow Books

Wickham-Jones, C. \& Downes, J. 2007. Long Howe, Orkney (St Andrew's and Deerness parish), excavation. Discovery and Excavation in Scotland 8, 147

Wickham-Jones, C. \& Firth, C. 2000. Mesolithic settlement of northern Britain: First results of fieldwork in Caithness and Orkney. In R. Young (ed.), Mesolithic Lifeways: Current research from Britain and Ireland, 119-32. Leicester: University of Leicester

Wicks, K., Pirie, A. \& Mithen, S. 2014. Settlement patterns in the late Mesolithic of western Scotland: The implications of Bayesian analysis of radiocarbon dates and inter-site technological comparisons. Journal of Archaeological Science 41, 406-22

Woodman, P.C. \& McCarthy, M. 2003. Contemplating some awful(ly interesting) vistas: Importing cattle and red deer into prehistoric Ireland. In Armit et al. 2003, 31-9 


\begin{tabular}{|c|c|c|c|c|c|c|c|c|c|}
\hline OxA no. & Site name & Island group & Material & Species/type & Context & $\begin{array}{l}\text { Radio- } \\
\text { carbon age } \\
\quad(B P)\end{array}$ & $\begin{array}{l}\delta^{13} \mathrm{C}(\% \circ) \\
\text { (error } \pm \\
0.2 \text { per } \\
\text { mille) } \\
\end{array}$ & $\begin{array}{l}\text { Calibrated } \\
\text { date range (cal } \\
\text { BC) at } 95 \% \\
\text { confidence } \\
\end{array}$ & Reference \\
\hline 28906 & An Doirlinn & Outer Hebrides & Wood charcoal & Corylus (hazel) - roundwood & Hearth F16 [74] & $4185 \pm 28$ & -28.4 & $2890-2670$ & $\begin{array}{l}\text { Garrow \& Sturt } \\
\text { in press }\end{array}$ \\
\hline 28907 & An Doirlinn & Outer Hebrides & Wood charcoal & Alnus (alder) & Levelling layer [54] & $4269 \pm 27$ & -26.6 & $2920-2880$ & $\begin{array}{l}\text { Garrow \& Sturt } \\
\text { in press }\end{array}$ \\
\hline 28908 & An Doirlinn & Outer Hebrides & Wood charcoal & Calluna (heather) & Hearth F10 [44] & $3908 \pm 26$ & -27.6 & $2470-2300$ & $\begin{array}{l}\text { Garrow \& Sturt } \\
\text { in press }\end{array}$ \\
\hline 28909 & An Doirlinn & Outer Hebrides & Wood charcoal & Alnus (alder) - roundwood & Hearth F8 [37] & $4110 \pm 27$ & -25.9 & $2860-2580$ & $\begin{array}{l}\text { Garrow \& Sturt } \\
\text { in press }\end{array}$ \\
\hline 28910 & An Doirlinn & Outer Hebrides & Wood charcoal & Alnus (alder) - roundwood & Hearth F8 [37] & $4141 \pm 27$ & -26.0 & $2870-2630$ & $\begin{array}{l}\text { Garrow \& Sturt } \\
\text { in press }\end{array}$ \\
\hline 28950 & An Doirlinn & Outer Hebrides & Charred residue & $\begin{array}{l}\text { On 'Hebridean Neolithic' } \\
\text { pottery - external }\end{array}$ & Occupation layer [82] & $4505 \pm 29$ & -26.6 & $3350-3100$ & $\begin{array}{l}\text { Garrow \& Sturt } \\
\text { in press }\end{array}$ \\
\hline 29156 & An Doirlinn & Outer Hebrides & Wood charcoal & Calluna sp. (heather) - twig & Occupation layer [82] & $4501 \pm 31$ & -27.7 & $3350-3100$ & $\begin{array}{l}\text { Garrow \& Sturt } \\
\text { in press }\end{array}$ \\
\hline 29157 & An Doirlinn & Outer Hebrides & Wood charcoal & Malvidae (apple/pear) - twig & Occupation layer [65] & $4056 \pm 30$ & -26.0 & $2840-2480$ & $\begin{array}{l}\text { Garrow \& Sturt } \\
\text { in press }\end{array}$ \\
\hline 29158 & An Doirlinn & Outer Hebrides & Charred residue & $\begin{array}{l}\text { On 'Hebridean Neolithic' } \\
\text { pottery - external }\end{array}$ & Levelling layer [64] & $4126 \pm 32$ & -27.0 & $2870-2580$ & $\begin{array}{l}\text { Garrow \& Sturt } \\
\text { in press }\end{array}$ \\
\hline 29159 & An Doirlinn & Outer Hebrides & Wood charcoal & $\begin{array}{l}\text { Pinus sylvestris/mugo (Scots/ } \\
\text { Mountain pine) - twig }\end{array}$ & Hearth F14 [76] & $4290 \pm 31$ & -26.2 & $3010-2880$ & $\begin{array}{l}\text { Garrow \& Sturt } \\
\text { in press }\end{array}$ \\
\hline 29160 & An Doirlinn & Outer Hebrides & Wood charcoal & Alnus (alder) & Hearth F9 [39] & $4063 \pm 30$ & -25.2 & $2850-2490$ & $\begin{array}{l}\text { Garrow \& Sturt } \\
\text { in press }\end{array}$ \\
\hline 29161 & An Doirlinn & Outer Hebrides & Wood charcoal & $\begin{array}{l}\text { Alnus (alder) - twig, } 2 \text { years } \\
\text { old }\end{array}$ & Post-hole F13 [60] & $4334 \pm 31$ & -26.1 & $3020-2890$ & $\begin{array}{l}\text { Garrow \& Sturt } \\
\text { in press }\end{array}$ \\
\hline 28953 & Loch Arnish & Outer Hebrides & Charred residue & $\begin{array}{l}\text { On 'Hebridean Neolithic' } \\
\text { pottery - internal }\end{array}$ & $\begin{array}{l}\text { Base of loch, adjacent to probable } \\
\text { Neolithic settlement }\end{array}$ & $4620 \pm 30$ & -26.3 & $3510-3350$ & $\begin{array}{l}\text { Sheridan et al. } \\
2014\end{array}$ \\
\hline $\begin{array}{l}28861 \\
28862\end{array}$ & Braes of Ha' Breck & $\begin{array}{l}\text { Orkney } \\
\text { Orkney }\end{array}$ & Charred grain & Hordeum (barley), naked & House 3, charred layer [1222] & $\begin{array}{l}4474 \pm 30 \\
4444+30\end{array}$ & -22.7 & $3340-3030$ & Thomas 2007 \\
\hline $\begin{array}{l}28862 \\
28863\end{array}$ & Braes of Ha' Breck & Orkney & Charred grain & $\begin{array}{l}\text { Hordeum (barley), naked } \\
\text { Hordeum (barley), naked }\end{array}$ & $\begin{array}{l}\text { House 3, south hearth [1194] } \\
\text { House 3, closing deposit in house } \\
\text { entrance [197] }\end{array}$ & $\begin{array}{l}4444 \pm 30 \\
4448 \pm 30\end{array}$ & -23.4 & $\begin{array}{l}3330-2940 \\
3340-2940\end{array}$ & $\begin{array}{l}\text { Ihomas } 2007 \\
\text { Thomas } 2007\end{array}$ \\
\hline 28983 & Braes of Ha' Breck & Orkney & Wood charcoal & $\begin{array}{l}\text { Salicaceae (willow) - } \\
\text { roundwood }\end{array}$ & Old land surface [1232] & $4640 \pm 32$ & -26.8 & $3520-3360$ & Thomas 2007 \\
\hline 29154 & Braes of Ha' Breck & Orkney & Wood charcoal & $\begin{array}{l}\text { Salicaceae (willow) - } \\
\text { roundwood }\end{array}$ & Old land surface [1232] & $4662 \pm 33$ & -26.1 & $3620-3360$ & Thomas 2007 \\
\hline $\begin{array}{l}29602 \\
X-2555-50\end{array}$ & Braes of Ha' Breck & Orkney & Charred grain & Hordeum (barley), naked & House 3, charred layer [1104] & $4386 \pm 30$ & -21.7 & $3090-2920$ & Thomas 2007 \\
\hline 28951 & Eilean an Tighe & Outer Hebrides & Charred residue & $\begin{array}{l}\text { On 'Hebridean Neolithic' } \\
\text { pottery - internal }\end{array}$ & $\begin{array}{l}364 \text { on exterior \& } 1953413 \text { on } \\
\text { interior. Bag labelled NMS X. } \\
\text { EOA 364.(8) (1953.Y) Area Y }\end{array}$ & $4610 \pm 29$ & -25.6 & $3510-3340$ & Scott 1951 \\
\hline 28952 & Eilean an Tighe & Outer Hebrides & Charred residue & $\begin{array}{l}\text { On 'Hebridean Neolithic' } \\
\text { pottery - internal }\end{array}$ & $\begin{array}{l}\text { Sherd marked EOA } 400 \& \text { ZE on } \\
\text { exterior and } 1953.449 \text { on } \\
\text { interior. Bag labelled NMS X. } \\
\text { EOA 400.(3) (1953.449) } \\
\text { Area ZE }\end{array}$ & $4672 \pm 30$ & -26.3 & $3620-3370$ & Scott 1951 \\
\hline 29162 & Eilean an Tighe & Outer Hebrides & Charred residue & $\begin{array}{l}\text { On 'Hebridean Neolithic' } \\
\text { pottery - internal }\end{array}$ & $\begin{array}{l}\text { Sherd labelled 2B in old black } \\
\text { ink, \& } 1953388 \text { in white. Bag } \\
\text { labelled NMS X.EOA } 339\end{array}$ & $1702 \pm 26$ & -27.8 & AD $260-400$ & Scott 1951 \\
\hline 28454 & Green & Orkney & Charred grain & Hordeum (barley) & $\begin{array}{l}\text { Structure 1, upper hearth } \\
\text { fill [116] }\end{array}$ & $4472 \pm 31$ & -21.3 & $3340-3030$ & Miles 2010 \\
\hline 28864 & Green & Orkney & Charred grain & $\begin{array}{l}\text { Hordeum/triticum } \\
\text { (barley/wheat) }\end{array}$ & Midden [214] & $4463 \pm 30$ & -23.5 & $3340-3020$ & Miles 2010 \\
\hline
\end{tabular}


Appendix 1. (Continued)

\begin{tabular}{|c|c|c|c|c|c|c|c|c|c|}
\hline Оха по. & Site name & Island group & Material & Species/type & Context & $\begin{array}{l}\text { Radio- } \\
\text { carbon age } \\
\text { (BP) }\end{array}$ & $\begin{array}{c}\delta^{13} \mathrm{C}(\% \mathrm{o}) \\
\text { (error } \pm \\
0.2 \text { per } \\
\text { mille) }\end{array}$ & $\begin{array}{c}\text { Calibrated } \\
\text { date range (cal } \\
B C) \text { at } 95 \% \\
\text { confidence }\end{array}$ & Reference \\
\hline 28984 & Green & Orkney & Wood charcoal & $\begin{array}{l}\text { Calluna (heather) - twig with } \\
\text { bark }+7 \text { growth rings }\end{array}$ & Post-hole fill [328] & $4676 \pm 32$ & -26.3 & $3620-3370$ & Miles 2010 \\
\hline 29155 & Green & Orkney & Charred grain & Hordeum (barley) naked? & $\begin{array}{l}\text { Structure 1, base of hearth, } \\
\text { fill [290] }\end{array}$ & $4489 \pm 32$ & -22.8 & $3350-3040$ & Miles 2010 \\
\hline 28903 & Le Pinacle & Channel Islands & Wood charcoal & Ulex (gorse) - roundwood & Hearth XY2-YZ2 & $2114 \pm 24$ & -25.8 & $200-50$ & $\begin{array}{l}\text { Godfray \& } \\
\quad \text { Burdo 1949; } \\
\text { Patton 1991 }\end{array}$ \\
\hline 28904 & Le Pinacle & Channel Islands & Wood charcoal & $\begin{array}{l}\text { Calluna (heather) - twig with } \\
\text { bark, } 16 \text { rings visible }\end{array}$ & Hearth XY2-YZ2 & $3101 \pm 24$ & -24.8 & $1430-1300$ & $\begin{array}{l}\text { Godfray \& } \\
\quad \text { Burdo 1949; } \\
\text { Patton } 1991\end{array}$ \\
\hline 28905 & Le Pinacle & Channel Islands & Wood charcoal & Calluna (heather) - twig & Hearth 'B3 Occupation' & $3107 \pm 24$ & -24.8 & $1430-1300$ & $\begin{array}{l}\text { Godfray \& } \\
\text { Burdo 1949; } \\
\text { Patton } 1991\end{array}$ \\
\hline 28668 & L'Eree & Channel Islands & Wood charcoal & $\begin{array}{l}\text { Rosceae maloideae } \\
\text { (hawthorn family) }\end{array}$ & Hearth F7 [74] & $5338 \pm 34$ & -24.9 & $4320-4050$ & $\begin{array}{l}\text { Garrow \& Sturt } \\
\text { in press }\end{array}$ \\
\hline 28669 & L'Eree & Channel Islands & Wood charcoal & $\begin{array}{l}\text { Rosceae maloideae } \\
\text { (hawthorn family) }\end{array}$ & Hearth F7 [74] & $5356 \pm 36$ & -25.4 & $4330-4050$ & $\begin{array}{l}\text { Garrow \& Sturt } \\
\text { in press }\end{array}$ \\
\hline 28670 & L'Eree & Channel Islands & Charred residue & $\begin{array}{l}\text { On undiagnostic pottery - } \\
\text { external }\end{array}$ & Ditch F21 [130] & $5985 \pm 36$ & -22.3 & $4980-4790$ & $\begin{array}{l}\text { Garrow \& Sturt } \\
\text { in press }\end{array}$ \\
\hline 28900 & L'Eree & Channel Islands & Wood charcoal & Laburnum, anagyroides type & Hearth F9 [78] & $5260 \pm 27$ & -23.8 & $4230-3990$ & $\begin{array}{l}\text { Garrow \& Sturt } \\
\text { in press }\end{array}$ \\
\hline 28901 & L'Eree & Channel Islands & Wood charcoal & Ulex (gorse) & Pit F18 [116] & $5356 \pm 28$ & -24.4 & $4320-4060$ & $\begin{array}{l}\text { Garrow \& Sturt } \\
\text { in press }\end{array}$ \\
\hline 28955 & Loch An Duna & Outer Hebrides & Charred residue & $\begin{array}{l}\text { On 'Hebridean Neolithic' } \\
\text { pottery - internal }\end{array}$ & $\begin{array}{l}\text { Base of loch, adjacent to probable } \\
\text { Neolithic settlement }\end{array}$ & $4658 \pm 30$ & -26.3 & $3520-3370$ & $\begin{array}{l}\text { Sheridan et al. } \\
\quad 2014\end{array}$ \\
\hline 28954 & Loch Bhorghastail & Outer Hebrides & Charred residue & $\begin{array}{l}\text { On 'Hebridean Neolithic' } \\
\text { pottery - internal }\end{array}$ & $\begin{array}{l}\text { Base of loch, adjacent to probable } \\
\text { Neolithic settlement }\end{array}$ & $4749 \pm 30$ & -21.6 & $3640-3380$ & $\begin{array}{l}\text { Sheridan et al. } \\
\quad 2014\end{array}$ \\
\hline 28948 & L’Ouzière & Channel Islands & Charred residue & $\begin{array}{l}\text { On 'VSG cordons' pottery - } \\
\text { external }\end{array}$ & $\begin{array}{l}\text { Peat horizon eroding from cliff } \\
\text { section }\end{array}$ & $6040 \pm 33$ & -27.4 & $5030-4840$ & $\begin{array}{l}\text { Patton \& } \\
\quad \text { Finlaison } 2001\end{array}$ \\
\hline 28949 & L'Ouzière & Channel Islands & Charred residue & $\begin{array}{l}\text { On 'VSG cordons' pottery - } \\
\text { external }\end{array}$ & $\begin{array}{l}\text { Peat horizon eroding from cliff } \\
\text { section }\end{array}$ & $6057 \pm 33$ & -27.2 & $5050-4850$ & $\begin{array}{l}\text { Patton \& } \\
\quad \text { Finlaison } 2001\end{array}$ \\
\hline 29163 & Northton & Outer Hebrides & Antler & Red deer & Neolithic midden & $4021 \pm 30$ & -21.8 & $2620-2470$ & $\begin{array}{l}\text { Simpson et al. } \\
2006\end{array}$ \\
\hline 29340 & Old Quay & Isles of Scilly & Charred residue & $\begin{array}{l}\text { On 'South-western Bowl' } \\
\text { pottery - external }\end{array}$ & Post-hole F16 [139], Tr. 28 & $4407 \pm 30$ & -29.5 & $3270-2920$ & $\begin{array}{l}\text { Garrow \& Sturt } \\
\text { in press }\end{array}$ \\
\hline 31868 & Old Quay & Isles of Scilly & Charcoal (seed) & Triticum (wheat) & Pit F23 [171], Tr. 28 & $4506 \pm 31$ & -22.7 & $3350-3100$ & $\begin{array}{l}\text { Garrow \& Sturt } \\
\text { in press }\end{array}$ \\
\hline 31869 & Old Quay & Isles of Scilly & Charcoal (seed) & Hordeum (barley) & Post-hole F27 [196], Tr. 28 & $1724 \pm 25$ & -23.3 & AD $250-390$ & $\begin{array}{l}\text { Garrow \& Sturt } \\
\text { in press }\end{array}$ \\
\hline 31870 & Old Quay & Isles of Scilly & Charcoal (seed) & Triticum (wheat) & Pit/P-H F29 [203], Tr. 28 & $1704 \pm 27$ & -23.8 & AD $250-400$ & $\begin{array}{l}\text { Garrow \& Sturt } \\
\text { in press }\end{array}$ \\
\hline 31871 & Old Quay & Isles of Scilly & $\begin{array}{l}\text { Charcoal } \\
\text { (wood) }\end{array}$ & Ulex (gorse) & Large pit F33 [217], Tr. 28 & $4442 \pm 35$ & -25.8 & $3330-2930$ & $\begin{array}{l}\text { Garrow \& Sturt } \\
\text { in press }\end{array}$ \\
\hline 31872 & Old Quay & Isles of Scilly & $\begin{array}{l}\text { Charcoal } \\
\text { (wood) }\end{array}$ & Prunus family & Pit F56 [275], Tr. 38 & $4511 \pm 33$ & -24.0 & $3360-3100$ & $\begin{array}{l}\text { Garrow \& Sturt } \\
\text { in press }\end{array}$ \\
\hline 31873 & Old Quay & Isles of Scilly & $\begin{array}{l}\text { Charcoal } \\
\text { (wood) }\end{array}$ & Leguminosae family & Post-hole F69 [305], Tr. 39 & $4414 \pm 30$ & -24.2 & $3310-2920$ & $\begin{array}{l}\text { Garrow \& Sturt } \\
\text { in press }\end{array}$ \\
\hline 31990 & Old Quay & Isles of Scilly & $\begin{array}{l}\text { Charcoal } \\
\text { (wood) }\end{array}$ & Leguminosae family & Large pit F33 [211], Tr. 28 & $4451 \pm 31$ & -25.6 & $3340-2950$ & $\begin{array}{l}\text { Garrow \& Sturt } \\
\text { in press }\end{array}$ \\
\hline 32024 & Old Quay & Isles of Scilly & Charred residue & $\begin{array}{l}\text { On 'Scillonian Bronze Age' } \\
\text { pottery - external }\end{array}$ & Oval pit F22 [169], Tr. 32 & $3413 \pm 32$ & -27.6 & $1870-1630$ & $\begin{array}{l}\text { Garrow \& Sturt } \\
\text { in press }\end{array}$ \\
\hline 28902 & $\begin{array}{l}\text { Royal Hotel, } \\
\text { St Peter Port }\end{array}$ & Channel Islands & Wood charcoal & Unidentifiable & Pit F44 & $6139 \pm 31$ & -26.7 & $5210-5000$ & Sebire 2011 \\
\hline
\end{tabular}




\section{Garrow et al. RADIOCARBON DATING ON ISLANDS WITHIN THE 'WESTERN SEAWAYS' OF BRITAIN}

\section{APPENDIX 2. RADIOCARBON DATA TREATMENT AND MODELLING}

\section{DATA TREATMENT}

Results produced on charcoal that was not identified to species level were treated as termini post quos, reflecting the potential for inbuilt 'old wood' offsets. Results on the charred residues on the exterior of pottery sherds were treated as if they dated the use of the vessel, though it should be acknowledged that radiocarbon measurements on the exterior of some sherds may include inbuilt offsets derived from an 'old wood' fuel effect (Nakamura et al. 2001; Hedges et al. 1992).

Demonstrably shortlife samples were included in the model as active likelihoods. Where possible, the relative ages of samples were included in their analysis in a model reflecting site stratigraphy or associations with diagnostic pottery typologies. In several cases however, such as at An Doirlinn, the recorded site stratigraphy and radiocarbon results showed poor agreement, indicative of potentially redeposited and/or intrusive material.

\section{SITE MODELS: CHANNEL ISLANDS}

\section{L'Erée, Guernsey}

L'Erée comprises an Early/Middle Neolithic settlement site stratified underneath Late Neolithic and Early Bronze Age deposits. The Middle Neolithic settlement features included several stone-filled hearths, post-holes, and pits. Eight radiocarbon dates exist from samples from L'Erée. Two of these were acquired as a result of Cunliffe's 1998 excavations (Cunliffe \& de Jersey 2000, 892); the remainder were from excavations for the Stepping Stones project in 200811. Cunliffe's samples were not identified to species level and were on charcoal that was not demonstrably shortlife, and these therefore have not been included in the models presented here. Of the more recently produced results, one was on the charred external residue on a pottery sherd from a ditch fill. This pottery is of an undiagnostic, but conceivably early, form and is interpreted as potentially representing Villeneuve Saint Germain-phase activity, along with several other diagnostic finds from the site (Garrow \& Sturt in press). Four other results (including two statistically consistent measurements on the same sample OxA-28669 and OxA-28668; $\mathrm{T}^{\prime}=0.1 ; \mathrm{T}^{\prime} 3.8 ; \mathrm{df}=1$ ) from the site were produced on charcoal from features or deposits associated with the use of diagnostic Middle Neolithic Pinacle-Fouaillages pottery. The results from L'Erée have been modelled to reflect the pottery typology development, with the result on the potentially Villeneuve Saint Germain sherd modelled to be earlier than the results associated with the Pinacle-Fouaillages pottery.

\section{L’Ouzière, Jersey}

Two statistically consistent radiocarbon measurements (OxA-28948; OxA-28949; T'-0.1; T'5\%=3.8; df=1) were produced on the charred external residue on a particularly diagnostic Villeneuve-Saint-Germain 'cordons'-type sherd. As noted above, while there are acknowledged issues with measurements produced on some externally charred sherds, we have chosen to include these results in the model. The results are consistent with the broad understanding of this pottery type in mainland France (Marcigny et al. 2010).

\section{La Hougue Bie, Jersey}

La Hougue Bie is a monumental passage grave. Nine radiocarbon dates on charcoal samples exist from the site (Patton 1995; Patton et al. 1999). The dates have recently been reviewed by Schulting et al. (2010). The results were produced on charcoal samples which were not identified to species level, and have therefore been presented here as termini post quos for activity at the site. While it is possible to build internally consistent models of the available measurements reflecting their parent stratigraphic associations (model not shown; cf. Schulting et al. 2010), the nature of the dated samples, the complexity of activity at the site, and the potential for redeposition of material arguably makes this unwise. The range of ages from the site, and especially from the premonument terrace, and from stratigraphically later deposits from the monument, mean again that it would be unwise to speculate either about the timing, tempo, or duration of use of such a potentially complex site from the available data.

\section{Le Déhus, Guernsey}

The results from Le Déhus are presented in a single bounded phase, representing a period of early use of the monument, following the model of Schulting et al. (2010). A much later result produced from the site has been presented here as an outlier (OxA-21198).

\section{Le Pinacle, Guernsey}

The multi-phase site at Le Pinacle includes an Early Neolithic land surface sealed below later prehistoric Early Bronze Age and Iron Age deposits. The Neolithic component of the site included midden deposits and hearths. Four radiocarbon dates were produced on samples thought to be associated with Neolithic activity at the site. BM-370 and OxA-28905 were both produced on charcoal from the same sample tray, but these two results are very different $\left(T^{\prime}=358.1 ; T^{\prime} 5 \%=3.8\right.$; $\mathrm{df}=1)$; only the later result $(\mathrm{OxA}-28905)$ was identified to species level, and suggests that more complex deposit formation or post-depositional activity may have occurred than was originally envisaged in the excavation or potentially that postexcavation mixing-up of material may have occurred. Another two results recorded as coming from the same supposedly Neolithic hearth (OxA-28904 and OxA-28903) are also much later than the earliest result from the site (BM-370) on unidentified charcoal. The OxA- results are too late for the period of interest here and have not been presented in the figures. BM-370 may be associated with early Neolithic activity at the site, but was not identified to species level, and is presented here as a terminus post quos. The complexity of activity at Le Pinacle, the limited numbers of radiocarbon dates, and the potentially complex issues with sample taphonomy mean that the chronology of the site is poorly understood. 


\section{Les Fouaillages, Guernsey}

Les Fouaillages is a trapezoidal long mound associated with both 'transitional' Villeneuve-Saint-Germain/Cerny and Pinnacle-Fouaillages ceramics (Pioffet 2013). The monument was excavated by Ian Kinnes $(1982 ; 1986)$. There are eight relevant published radiocarbon dates produced on samples from the Les Fouaillages monument, and a recent reanalysis presented by Schulting et al. (2010). Seven of the results were produced on charcoal samples which were not identified to species level. Schulting et al. $(2010,163)$ cite Kinnes as stating that the radiocarbon samples 'were carefully selected from discrete deposits of small roundwood, ie small branches and twigs'. The nature of these samples still means however that they could include potential 'old wood' offsets, and the nature of the parent deposits - for example in deriving from the mound body in phase 1 - means that there is the potential that residual or mixed age material was included in these samples. The results from the site on charcoal were subject to a measurement issue at the British Museum laboratory (Bowman et al. 1990), and the revised measurement is presented in Appendix S. 3. These results have been presented as termini post quos. One measurement produced more recently, SUERC-23729, was made on a charred residue on a transitional Villeneuve-Saint-Germain/ Cerny-type sherd, though it is not specified whether from the interior or exterior of the potsherd, and the residue could therefore include a fuel derived 'old wood' offset (see discussion above). The association of this measurement with the construction of the monument cannot be established. Only the result on the sherd has been included in the model presented here.

\section{Royal Hotel, St Peter Port, Guernsey}

Two radiocarbon dates (OxA-12996, OxA-28902) were produced on unidentifiable charcoal from feature 44, a pit/ post-hole just outside a putative Early Neolithic structure associated with Villeneuve-Saint-Germain 'cordons' ceramics. The results cannot be demonstrated to be shortlife, and are therefore included in the model as termini post quos.

SITE MODELS: ISLES OF SCILLY

\section{Old Quay, St Martin's}

Radiocarbon dates from Old Quay demonstrate three phases of activity at the site (echoing the material culture recovered there) relating to the Neolithic, the Early Bronze Age, and the Romano-British period. Only the six results associated with the Neolithic phase, characterised by pits and postholes containing Hembury/Western Bowl style pottery, are presented here. These results have been presented in a single bounded phase representing Neolithic activity at the site.

\section{SITE MODELS: OUTER HEBRIDES}

\section{Allt Chrisal, Barra}

Three radiocarbon dates exist from site T26A, Allt Chrisal. These derive from different site phases associated with Neolithic activity. From phase 1, associated with post-pits for substantial wooden structures, a sample (GU-3922) was recovered. Subsequently, activity from phase 4 is dated by GU-3467, and sample GU-3923 was produced from a sample associated with the abandonment of the site. The relationship between the parent deposits and the site phasing provides a relative sequence for the radiocarbon dates from this site, which is applied in the model presented here; however, the potential for residuality or redeposition should be noted, given the multiphase nature of the site. This, and the small number of radiocarbon dates from the site, means that the overall chronology of Allt Chrisal cannot be presented as a developed model.

\section{An Doirlinn, South Uist}

Twelve radiocarbon measurements from An Doirlinn were produced as part of the Stepping Stones project. The samples submitted were from deposits which could be clearly stratigraphically related during excavation. Modelling these results to reflect all of the stratigraphic relationships between sampled deposits produces a model with a poor agreement index (model not shown). Given the complexity of site formation processes at An Doirlinn - whereby some deposits had come to be redeposited in a secondary or tertiary location and many features were cut into much earlier occupation deposits - it is very likely that at least some of the dated charred plant remains were themselves either redeposited in later contexts or reworked in other ways. Consequently, in the model presented here we have included measurements on samples from unsecure contexts (ie they were either from pits/post-holes cut down into earlier deposits or in layers that had clearly been redeposited) as termini post quos. The full report on the chronology for this site is presented in the site report (Garrow \& Sturt in press).

\section{Berneray Causeway/Rubh' a'Charnain Mhoir, North Uist}

Two radiocarbon dates were produced on birch charcoal from an irregular, large pit, containing large amounts of pottery, at Berneray Causeway/Rubh' a' Charnain Mhoir; these results are statistically consistent $\left(\mathrm{T}^{\prime}=0.6 ; \mathrm{T}^{\prime} 5 \%=3.8 ; \mathrm{df}=1\right)$.

\section{Bharpa Carinish, North Uist}

Five radiocarbon results exist from Bharpa Carinish, these were produced on shortlife charcoal samples from three hearth 'complexes' from the site (Crone 1993). One of these results (GU-2669) produced on charcoal from hearth 2 is much older than the other four statistically consistent measurements (GU-2458; GU-2671; GU-2670; GU-2672; $\left.\mathrm{T}^{\prime}=4.1 ; \mathrm{T}^{\prime} 5 \%=7.8 ; \mathrm{df}=3\right)$. GU-2669 was produced on charcoal from a hearth of Neolithic form, and the measurement could therefore reflect a statistical outlier, or a piece of residual charcoal. This result has not been included as an active likelihood in the model presented here. GU-2672 was produced on a charcoal sample from pit F97 underlying hearth 3, the final use of which was dated by GU-2671. GU-2669 (which was submitted to date the final use of hearth 2) underlay the deposit from which the sample for GU-2670 was recovered. The model presented here 


\section{Garrow et al. RADIOCARBON DATING ON ISLANDS WITHIN THE 'WESTERN SEAWAYS' OF BRITAIN}

represents the other results associated with the earlier prehistoric hearth complexes as deriving from a phase of activity, and reflects the stratigraphic sequence between the parent contexts for samples for GU-2672 and GU-2671.

\section{Dunasbroc, Lewis}

Nine radiocarbon dates have been produced on samples from Dunasbroc. Five of the samples produced Neolithic dates within the 4th millennium cal BC (three on Betula charcoal, one on Salix charcoal, and one on charred residue on a pot sherd). The older dates may represent Neolithic activity, as Hebridean Ware pottery was also recovered from the site. Only the 4th millennium cal BC results are included in the model shown here, which represents them as reflecting a single Neolithic phase of activity.

\section{Eilean an Tighe, North Uist}

Charred internal residues from two sherds of Hebridean ware pottery from Eilean an Tighe were used to produce statistically consistent radiocarbon dates (OxA-28951; OxA-28952; T' $=2.2 ; T^{\prime} 5 \%=3.8 ; \mathrm{df}=1$ ), dating the use of these vessels and associated activity at the site.

\section{Eilean Dombnuill, North Uist}

Fourteen published radiocarbon results are associated with Neolithic activity from Eilean Domhnuill, along with an associated multi-phase developmental model for the site. Analysis of the radiocarbon dates is still on going (Ian Armit pers. comm.). The published results, when modelled according with the published phasing, have poor agreement (model not shown), suggesting either a more complex taphonomy than has hither to be been recognised, or perhaps more likely (given the nature of the site) the redeposition of material. The model of the phased development of the site was re-run with the results subject to formal outlier analysis using the prior probability of 0.05 that each measurement was an outlier and the General T model (Bronk Ramsey 2009b). This analysis suggested that several measurements were problematic: OxA-9080, OxA-9159, and AA-29713 were all far too late for their position in the phased development of the site; OxA-9085 and OxA-9083 in contrast were too early for their position in the phased development of the site. These late results were not included as active likelihoods in the model presented here, while
OxA-9085 and OxA-9083 are represented as a termini post quos. The rest of the results are presented here within a sequence of consecutive site development phases. Further analysis of this site may develop the model applied.

\section{Loch An Duna, Lewis}

A single result (OxA-28955) produced on internal charred residue from a Neolithic Hebridean-style pottery vessel estimates the use of the pot.

\section{Loch Arnish, Lewis}

A single result (OxA-28953) produced on internal charred residue from a Neolithic Hebridean-style pottery vessel estimates the use of the pot.

\section{Loch Bhorghastail, Lewis}

A single result (OxA-28954) produced on internal charred residue from a Neolithic Hebridean-style pottery vessel estimates the use of the pot.

\section{Northton, Harris}

A single reliable radiocarbon date relating to the Neolithic phase of occupation at Northton, Harris exists in the published literature (BM-705). One additional date, obtained from bulked charocal (Gak-846), appeared significantly too early for the associated material culture and is thus not included as an active likelihood in the analysis presented here (see Simpson et al. 2006, 44; Spriggs \& Anderson 1993).

\section{Shulishader, Lewis}

A hafted stone axe-head was recovered from peat at Shulishader. The axe-haft was a single piece of Rosaceae sp. wood, and the axe-head possibly a piece of Antrim porcellanite. A single radiocarbon result on the axe-haft dates its use.

\section{ORKNEY AND ISLE OF MAN}

Details of the modelling approaches for Orkney are given in Griffiths (2016), and details of the radiocarbon analysis for the Isle of Man are given in Whittle et al. (2011).

\section{RÉSUMÉ}

Marchepieds vers le néolithique? Datation au $C^{14} d u$ néolithique ancien sur les îles dans les limites des voies maritimes occidentales de la Grande Bretagne de Duncan Garrow, Seren Griffiths, Hugo Anderson-Whymark et Fraser Sturt

Les voies maritimes occidentales, un arc de mer qui s'étale des îles Anglo-Normandes au sud, remontant par les îles de Scilly et l'île de Man et les Hébrides Extérieures jusqu'aux Orcades au nord, ont depuis longtemps été considérées comme cruciales pour notre compréhension des procédés qui ont conduit à l'arrivée du néolithique en

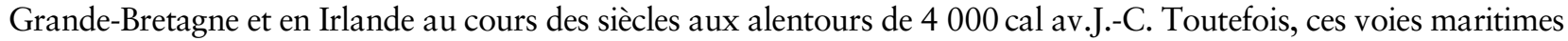
occidentales n'ont été examinées en détail dans aucune des récentes études traitant de la chronologie au 
radiocarbone du néolithique le plus ancien de cette région plus étendue. Cette étude présente une synthèse de toutes les dates au radiocarbone existantes pour les $5^{\text {ème }}$ et $4^{\text {ème }}$ millénaires cal av.J.-C. pour les îles dans le périmètre des voies maritimes occidentales, y compris 50 nouveaux résultats obtenus spécialement pour cette étude.Alors que nous nous concentrons ici sur le terme insulaire au sens littéral, les résultats du projet ont des implications riches de conséquences pour notre compréhension de la transition mésolithique-néolithique en Grande-Bretagne, en Irlande et au delà. Grosso modo les découvertes s'insèrent bien dans le modèle: Gathering Time (Whittle et al. 2011), qui suggère que le néolithique le plus ancien daté dans cette zone se situe dans l'éventail c. 3 900-3 700 cal av.J.-C. Cependant, on a aussi noté que notre compréhension chronologique actuelle repose sur un nombre comparativement petit de dates réparties sur une vaste zone. Par conséquent, nous suggérons que sont nécessaires à la fois de nouveaux travaux ciblés et une approche qui comprenne un élément de typo-chronologie (ainsi que des datations absolues) si nous voulons faire avancer notre compréhension des procédés associés à l'apparition de la première culture matérielle néolithique et de ses pratiques dans cette région clé

\section{ZUSAMMENFASSUNG}

Trittsteine zum Neolithikum? Die Radiokarbondatierung des Frühneolithikums auf Inseln der "westlichen Seewege" von Großbritannien, von Duncan Garrow, Seren Griffiths, Hugo Anderson-Whymark und Fraser Sturt

Die westlichen Seewege - ein Meeresbogen von den Kanalinseln im Süden bis zu den Scilly-Inseln, der Isle of Man und den Äußeren Hebriden bis Orkney im Norden - werden seit langem als entscheidend für unser Verständnis der Prozesse gesehen, die zur Ankunft des Neolithikums in Großbritannien und Irland in den Jahrhunderten um $4000 \mathrm{cal}$ BC führten. In die jüngeren Untersuchungen zur Radiokarbonchronologie des frühesten Neolithikums in dieser weiteren Region wurden die westlichen Seewege jedoch nicht detailliert einbezogen. Dieser Beitrag stellt eine Synthese aller existierenden C14-Daten des 5. und 4. Jahrtausends cal BC vor, die von Inseln der westlichen Seewege stammen, einschließlich 50 neuer Ergebnisse, die für diese Untersuchung gewonnen wurden. Auch wenn der Fokus dieser Forschung „insular“ im wörtlichen Sinne ist, haben die Resultate des Projekts weitreichende Auswirkungen auf unser Verständnis des Übergangs vom Mesolithikum zum Neolithikum in Großbritannien und Irland und darüber hinaus. Die Ergebnisse stimmen gut mit dem „Gathering Time“ Modell überein (Whittle et al. 2011), das nahe legt, dass das früheste datierte Neolithikum in dieser Region etwa in den Zeitrahmen 3900-3700 cal вс fällt. Jedoch muss auch festgestellt werden, dass unser gegenwärtiges chronologisches Verständnis auf vergleichsweise wenigen und über einen großen Raum verstreuten Daten basiert. Konsequenterweise wird vorgeschlagen, dass sowohl weitere zielgerichtete Untersuchungen notwendig sind als auch ein Forschungsansatz, der auch typochronologische Studien neben absoluten Datierungen umfasst, wenn wir unser Verständnis der Prozesse, die mit dem Auftreten der frühesten neolithischen materiellen Kultur und damit zusammenhängenden Handlungsweisen in dieser Region verbunden sind, verbessern wollen

\section{RESUMEN}

¿Trampolín hacia el Neolitico? Datación radiocarbónica del Neolítico inicial de las "rutas maritimas del oeste" en las islas de Gran Bretaña, por Duncan Garrow, Seren Griffiths, Hugo Anderson-Whymark y Fraser Sturt

Las rutas marítimas del oeste - un arco marítimo que se extiende desde las Islas del Canal en el Sur, hasta las Islas de Scilly, la Isla de Man y de las Islas Hébridas a las Orcadas en el norte- ha sido crucial para comprender la llegada del Neolítico a Gran Bretaña e Irlanda en cronologías en torno al 4000 cal BC. Sin embargo, no han sido consideradas en detalle en los estudios más recientes sobre la cronología radiocarbónica del Neolítico Antiguo a una escala más amplia. Este artículo presenta una síntesis de todas las dataciones radiocarbónicas disponibles para el V y IV milenio cal BC de las islas que forman las rutas marítimas del oeste, incluyendo 50 nuevos resultados obtenidos específicamente para este trabajo. A pesar de que el objetivo es claramente insular en su sentido más literal, los resultados del proyecto tienen mayores implicaciones para nuestra comprensión de la 
transición Mesolítico-Neolítico en Gran Bretaña, Irlanda e incluso más allá. Estos resultados encajan con el modelo Gathering time (Whittle et al. 2011), sugiriendo que las primeras evidencias del Neolítico en la zona se situarían cronológicamente en el intervalo c. 3900-3700 cal вс. Sin embargo, debemos igualmente resaltar que la interpretación cronológica del fenómeno está basada en algunas fechas dispersas a lo largo de una extensa área. Consecuentemente, en el futuro serán necesarios estudios específicos y enfoques que incorporen elementos de tipo-cronología (al igual que la cronología absoluta) si queremos ampliar nuestra comprensión del proceso asociado a la aparición de las primeras evidencias de cultura material y de prácticas neolíticas en esta región. 